\title{
LA NOCIÓN JURÍDICA DE EMPLEADOR ANTE EL DERECHO DEL TRABAJO
}

[The Legal Notion of the Employer in the Labor Law]

\author{
Pedro Irureta Uriarte* \\ Universidad Alberto Hurtado, Santiago de Chile
}

\begin{abstract}
RESUMEN
La noción jurídica del empleador ha sido tradicionalmente estructurada como contraparte en el contrato de trabajo y como una figura traslaticia de la del trabajador. Este vocablo ha prevalecido en la legislación chilena por sobre otros términos, como empresario o patrono, a objeto de reflejar más exactamente la posición que éste ocupa como receptor de los servicios subordinados prestados por el trabajador. Es esta característica la que prevalece en la definición de empleador, sin que sean necesarios otros requisitos extraordinarios vinculados a la capacidad civil o comercial de éste o al tipo de negocio del cual es titular.
\end{abstract}

\section{Palabras Clave}

Empleador - Trabajador - Subordinación laboral.

\begin{abstract}
The legal notion of the employer has been traditionally structured as a counterpart in the contract of employment and as a concept different from the employee. This term has prevailed over others, such as businessperson or master, in the Chilean in order to explain that this person receives subordinated services rendered by the employee. This is the prevailing characteristic in the definition of employer, without having the need for other extraordinary requirements related to civil or commercial capacity of the employer or of the business owned by him or her.
\end{abstract}

\section{KEYWORDS}

Employer - Employee - Labor subordination.

RECIBIDO el 24 de abril y ACEPTADo el 2 de junio de 2014

* Abogado y licenciado en derecho por la Pontificia Universidad Católica de Chile. Doctor en derecho por la Universidad Complutense de Madrid. Profesor titular de derecho del trabajo en la Universidad Alberto Hurtado. Correo electrónico: piruret@ uahurtado.cl 


\section{INTRODUCCIÓN}

La figura central del Código del Trabajo, y por cierto la más estudiada jurídicamente, es la del trabajador. Si bien en el ordenamiento laboral existen referencias directas a la empresa o al empleador, incluso algunas amparando su propio interés, no cabe duda que la mayor parte de las normas de la legislación social se enfocan a proteger al trabajador y a estructurar las consecuencias que se derivan de la prestación de servicios bajo subordinación o dependencia. Desde esta perspectiva, la figura del empleador no ha sido motivo de mayor desarrollo o análisis; es como si la legislación laboral partiera de la base que se trata de un concepto previamente conocido y sobre el cual no caben mayores distinciones o divergencias; salvo, por cierto, los supuestos patológicos de identificación empresarial.

La falta de un análisis más acabado sobre la figura del empleador en nuestro ordenamiento se ve reflejada, además, por el escaso interés que tanto la doctrina como la jurisprudencia le han dedicado a este tema ${ }^{1}$. Salvo algunos ensayos o monografías específicas sobre los grupos de empresa o sobre los alcances laborales derivados de la actuación de un ente de hecho ${ }^{2}$, lo cierto es que la doctrina nacional no ha desarrollado una dogmática muy acabada con respecto a la noción jurídica de empleador. Tampoco lo ha hecho la jurisprudencia, ya que más allá de algunos fallos vinculados a la existencia de indicios propios de una sola unidad económica, no existen demasiados pronunciamientos judiciales sobre la naturaleza del acreedor laboral y sobre los rasgos distintivos que éste debe tener para configurarlo como tal. Por el contrario, la mayor parte de las sentencias de los tribunales de justicia se han centrado en la idea del trabajador y de la subordinación laboral; y sólo a partir de ahí, se suele en algunas ocasiones hacerse cargo de la figura del empleador.

Asumiendo lo anterior, en el presente artículo se intenta desentrañar la exacta naturaleza jurídica del sujeto que actúa como receptor de los servicios prestados por el trabajador. Para estos efectos, en la primera parte de este estudio se resuelven algunos problemas terminológicos que históricamente han concurrido en la identificación de este sujeto contratante. A continuación,

${ }^{1}$ Algunos comentaristas del Código de 1931 ya advertían, en su momento, la falta de un estudio más exhaustivo sobre la figura del empleador. Véase, por ejemplo: LABARCA GODDARD, Eduardo, El concepto de patrón o empleador en la legislación chilena (Santiago, Editorial Jurídica de Chile, 1966), p. 5.

${ }^{2}$ Véanse por todos: Rojas Miño, Irene - Aylwin Chiorrini, Andrés, Los grupos de empresas en el derecho chileno del trabajo (Santiago, LexisNexis, 2006), pp. 7 ss.; IRURETA URIARTE, Pedro, La situación procesal de los entes de hecho en el proyecto de ley que sustituye el procedimiento laboral contemplado en el Libro V del Código del Trabajo, en, Cuadernos Judiciales, 8 (2004): Las reformas procesales pendientes, pp. 79 ss. 
se realiza un análisis sobre la posición jurídica que el empleador asume en el contexto del contrato de trabajo. Hay que tener en cuenta, en todo caso, que en este artículo no se analizan algunas figuras empleadoras que han intervenido en la práctica laboral (v. gr., los grupos de empresa, los entes de hechos o los supuestos de unidad económica), centrando el análisis en los elementos propios de la figura del empleador como sujeto del contrato de trabajo.

\section{LA IDENTIFICACIÓN TERMINOLÓGICA DEL ACREEDOR LABORAL}

\section{Generalidades.}

Más de alguien podrá estimar que los problemas terminológicos son cuestiones en extremo baladíes; que la aplicación del lenguaje natural, a pesar de sus matices, no debiera generar mayores inconvenientes al momento de interpretar una norma legal. Sin embargo, esa posición puede resultar bastante inexacta al momento de confrontar la utilización cotidiana de las palabras con su real significado jurídico. Lo cierto es que muchas veces los términos lingüísticos se encuentran íntimamente vinculados con implicancias conceptuales, y muchas cuestiones de carácter científico han terminado siendo simples problemas de léxico ${ }^{3}$. Los modos peculiares de expresión constituyen un hecho y obligan a que el jurista investigue el alcance de las palabras y expresiones empleadas, a objeto de desenmarañar las relaciones mutuas entre las diversas frases, "y ver si se ha desarrollado una terminología en alguna medida constante y libre de ambigüedades" ". Lo anterior tiene aún mayor relevancia cuando las expresiones son polifuncionales, ya que éstas pueden tener un distinto significado dependiendo del contexto en que vayan insertas 5 . Por otra parte, en variadas ocasiones la terminología se encuentra recargada de un elemento ideológico, en su sentido amplio, y esa dependencia

${ }^{3}$ Véase: Borrajo Dacruz, Efrén, Los auxiliares del comerciante en el derecho español, en Revista de Derecho Mercantil, 23, 63 (1957), p. 10. Véase también: AtienZA, Manuel, Introducción al derecho (México, Distribuciones Fontamara, 1998), pp. 11 ss.

${ }^{4}$ Véase: Ross, Alf, Sobre el derecho y la justicia (traducción castellana de Genaro R. Carrió, Buenos Aires, Universitaria de Buenos Aires, 1963), p. 153. Véase también: Olivecrona, Karl, Lenguaje jurídico y realidad ( $2^{a}$ edición, México, Distribuciones Fontamara, 1992), p. 59.

${ }^{5}$ Véase: CARrió, Genaro, Algunas palabras sobre las palabras de la ley (Buenos Aires, Abeledo-Perrot, 1971), p. 15. Y agrega en p. 21: "Los lenguajes naturales exhiben una textura abierta. Esto quiere decir que aún en el supuesto del empleo de palabras que no son de hecho usadas con vaguedad pueden presentarse perplejidades o desconciertos legítimos". Del mismo autor se puede consultar, además, su obra Sobre los límites del lenguaje normativo ( $1^{\mathrm{a}}$ reimpresión, Buenos Aires, Astrea, 2001), pp. 24 ss. 
hace que el concepto en muchas ocasiones no sea el más adecuado como instrumento de normación ${ }^{6}$.

Como es obvio, mediante el lenguaje se configuran las leyes, cuestión que obliga al intérprete a tener que descubrir las consecuencias que de ello se deriva ${ }^{7}$. Desde esta perspectiva, en el mundo del derecho, la determinación exacta de los vocablos adquiere una especial trascendencia si se busca desentrañar la esencialidad de los conceptos vertidos por la ley. A fin de cuentas, la vaguedad potencial de las palabras afecta a todas las que se usan cotidianamente, incluidas aquellas que aparecen en las normas jurídicas ${ }^{8}$. Y tal como ha señalado la doctrina, un uso descuidado o ligero de los conceptos puede arruinar irremediablemente un razonamiento y hasta todo un sistema normativo9. En razón de ello, el lenguaje jurídico no sólo debe ser preciso sino que, además, debe ser suficientemente apto para plasmar la realidad ${ }^{10}$.

Estas consideraciones resultan, por cierto, plenamente aplicables a la utilización legal del término empleador. La riqueza y variedad de matices que esta palabra encierra, tanto en el lenguaje natural como normativo, exige indagar en el verdadero alcance de la expresión, a objeto de que se centre adecuadamente el contenido jurídico-laboral del vocablo.

\section{La evolución lingüistica de un concepto.}

a) La denominación de la persona que utiliza los servicios materiales o inmateriales del trabajador ha recibido, tanto en la doctrina como en la legislación, un tratamiento diverso, pero que en general apunta a describir un mismo aspecto centrado en la titularidad de la actividad productiva y la posibilidad de exigir la prestación de servicios de acuerdo a los términos señalados en el contrato y en la ley.

A estos efectos, las legislaciones sociales han invocado, en diversos períodos, los vocablos patrono, empresario o empleador, para referirse a la figura del titular de la empresa y sujeto del contrato de trabajo ${ }^{11}$. A pesar de que las primeras leyes sociales también hacían referencia al capitalista o al fabricante, la tendencia con la llegada del siglo XX fue la de utilizar la palabra patrono como vocablo omnicomprensivo de la noción jurídica de lo que hoy deno-

\footnotetext{
${ }^{6}$ Véase: Ross, Alf, cit. (n. 4), pp. 153-154.

${ }^{7}$ Véase: Montoya Melgar, Alfredo, Ideología y lenguaje en las leyes laborales de España (1873-1978) (Madrid, Civitas, 1992), p. 19.

${ }^{8}$ Véase: CARrió, Genaro, Algunas palabras, cit. (n. 5), pp. 23-24.

9 Véase: Montoya Melgar, Alfredo, Sobre el derecho del trabajo y su ciencia, en Revista Española de Derecho del Trabajo, 52 (1991), p. 178.

${ }^{10}$ Véase: Olivecrona, Karl, cit. (n. 4), p. 59.

${ }^{11}$ Véase: Montoya Melgar, Alfredo, Ideología y lenguaje, cit. (n. 7), pp. 76 ss. y 122.
} 
minamos empleador. De esta forma, se lograba tomar distancia de una serie de expresiones utilizadas por el ordenamiento civil, penal o comercial, y que hacían referencia a las figuras del amo, principal o factor ${ }^{12}$.

La expresión "patrón" o "patrono", que reconoce su origen en el propio derecho romano, lleva envuelta la idea lingüística de una especie de defensor, protector o amparador de personas, sin perjuicio de su asimilación con la imagen señorial del directo dominio en los feudos de la Edad Media ${ }^{13}$. En efecto, en Roma, la figura que comentamos se aplicó tanto al ciudadano romano que protegía a otras personas que se hallaban en situación jurídica inferior -v. gr., un extranjero-, así como al antiguo señor de un esclavo que había sido manumitido ${ }^{14}$. Este esquema se vuelve a repetir, en cierta medida, con la aparición del maestro en la época de las corporaciones, y en la irrupción del arrendamiento de servicios del Código napoleónico ${ }^{15}$. Su utilización por algunos textos jurídicos rememora, por lo demás, una expresión más vinculada a las luchas existentes entre clases sociales ${ }^{16}$, o a la configuración del derecho del trabajo como un ordenamiento exclusivamente aplicable a tareas de carácter manual ${ }^{17}$.

En el derecho chileno, el artículo 2 CT. de 1931 ya hacía referencia

${ }^{12}$ Véanse, por ejemplo, los ya derogados artículos 1989 y 1991 CC. Con todo, la expresión "amo" aún permanece en el artículo 1993 CC. y en el artículo $447 \mathrm{~N}^{\circ} 1 \mathrm{CP}$. En el ámbito social, el artículo 2 de la Ley de accidentes de trabajo del año 1916, en una clara opción dominical o patrimonialista, también hacía referencia al "p a t r o n o " o “jefe de e mpresa” como "cualquiera persona natural o jurídica que por cuenta propia o ajena tome a su cargo la ejecución de un trabajo o la explotación de una industria que se hacen bajo su inmediata dirección”. Similares referencias podían encontrarse en el artículo 2 del Código del Trabajo de 1931, el cual equiparaba, por su parte, las expresiones "patrón" y "empleador"; mientras que en otros pasajes las utilizaba de manera independiente (v. gr., en el artículo $3^{\circ}$ y 108) o simplemente recurría al término empresa en oposición al concepto de trabajador, como ocurría en el caso del artículo 14 del citado cuerpo legal. Sobre el alcance de esta normativa, véase además: YAÑEz ANDRADE, Juan Carlos, Antecedentes y evolución histórica de la legislación social de Chile entre 1906 y 1924, en Revista de Estudios Histórico-Jurídicos, 21 (1999), pp. 203 ss.

${ }^{13}$ Véase: Diccionario de la lengua española (21 a edición, Madrid, Real Academia de la Lengua , 1992), II, p. 1550. Véase también: De la Villa GIL, Luis Enrique, La extinción del contrato de trabajo (Madrid, Consejo Superior de Investigaciones Científicas, 1960), p. 91.

${ }^{14}$ Véase por todos: Gómez-Iglesias Casal, Ángel, La influencia del derecho romano en las modernas relaciones de trabajo (Madrid, Civitas, 1995), pp. 50 ss.

${ }^{15}$ Véase: Bayón Chacón, Gaspar - Pérez Botija, Eugenio, Manual de derecho del trabajo (11 a edición, Madrid, Marcial Pons, 1977-1978), I, p. 196.

${ }^{16}$ Véase: Alonso García, Manuel, El sujeto acreedor de trabajo, en Revista Jurídica de Cataluña, 60 (1961) 1, p. 22.

${ }^{17}$ Véase: Montoy Melgar, Alfredo, Ideología y lenguaje, cit. (n. 7), p. 77. 
al "patrón o empleador" como la "persona natural o jurídica que, por cuenta propia o ajena, tenga a su cargo la explotación de una empresa o faena de cualquier naturaleza o importancia, en que trabajen obreros o empleados, cualquiera que sea su número". Si bien esta definición perduró hasta la publicación del Decreto-ley No 2.200 , de $1978^{18}$, lo cierto es que la conceptualización antedicha fue objeto de diversas críticas por parte de la dogmática ${ }^{19}$.

En todo caso, la palabra patrono fue descartada del ordenamiento laboral actual, y la verdad de las cosas es que ella se presenta demasiado imprecisa para graficar la exacta figura de uno de los sujetos del contrato de trabajo. Si bien, una parte de la doctrina la ha revitalizado en aquellos supuestos en que la relación jurídico-laboral se desarrolla en figuras sencillas mantenidas por un sólo trabajador -a diferencia de lo que ocurre en una actividad laboral compleja ${ }^{20}-$, lo cierto es que en la actualidad resulta inaplicable dentro del complejo esquema organizacional de la empresa moderna ${ }^{21}$.

b) En nuestros días, la asunción del contrato como un acto jurídico de carácter bilateral, deja en evidencia que la celebración de éste hace nacer un vínculo de clara función constitutiva y normativa de las obligaciones. Esta idea del contrato hace desterrar visiones despóticas de la empresa, en que el alcance de la figura del patrono se conjugaba con una concepción autoritaria de la unidad económica ${ }^{22}$; o con una clara tendencia paternalista de ciertas

${ }^{18}$ Un antecedente en el uso más generalizado de la voz empleador se introdujo en el artículo 12 de la Ley $\mathrm{N}^{\circ} 16.455$ (de 1966), según el cual “cuando esta ley usa los términos 'empleador' o 'trabajador', se entenderá que se refiere a 'empleadores y patrones' y a 'empleados y obreros', respectivamente".

${ }^{19}$ Véase, por ejemplo: EsCribar Mandiola, Héctor, Tratado de derecho del trabajo (Santiago, Zig-Zag 1944), I, p. 361. Con todo, la crítica fundamental de ESCRIBAR radicaba no tanto en la denominación utilizada sino en la circunstancia de que el patrón o empleador pudiese explotar una empresa "por cuenta propia o ajena". Y agrega: "Quien explota una empresa 'por cuenta ajena', es un mandatario o dependiente de la persona por cuya cuenta realiza la explotación, pero no patrón o empleador de los asalariados ocupados en ella, a menos que pacte y firme con éstos, por sí, los contratos de trabajo".

${ }^{20}$ Véase: Almansa Pastor, José Manuel, Los sujetos del derecho del trabajo y de la seguridad social, en II Encuentro Iberoamericano sobre Relaciones de Trabajo (Madrid, Servicio de Publicaciones Ministerio de 'y Seguridad Social, 1984), p. 42.

${ }^{21}$ No obstante, todavía existen legislaciones que la utilizan para conceptualizar a la persona que se beneficia de los servicios prestados por el trabajador, como es el caso, entre otros, del artículo 2 de la Ley general del trabajo de Bolivia; y el artículo 10 inciso $1^{\circ}$ de la Ley federal de México.

${ }^{22}$ Véase: Irureta Uriarte, Pedro, Empresa y personalidad jurídica, en Persona y Sociedad, 16 (2002) 3, pp. 287 ss. 
escuelas de política social23. Aquí no se trata de representar a "una persona física que mantiene con otra inferior un vínculo que no es dominical, pero sí de tipo en cierta forma señorial, unido por lo común a un derecho a beneficiarse del trabajo del protegido" ${ }^{24}$. Por el contrario, lo que se busca es configurar a un sujeto de la relación jurídica de trabajo, que en carácter de titular concurre a prestar su consentimiento a fin de perfeccionar un acto jurídico de efectos normativos y constitutivos.

Asimismo, la palabra "patrono" siempre resultaba inconveniente en atención a la convencionalidad que en muchos casos tiene el término, ya que en una sociedad anónima, o en una gran explotación colectiva, no es nada fácil personalizar al patrono. Si bien, antiguamente, se pretendía asignar un carácter protector al dirigente de la empresa, en relación con el obrero, hoy en día esa visión se encuentra ampliamente superada, pudiendo asumir la configuración externa del empleador, tanto un gerente como un consejo de administración o una junta de $\operatorname{socios}^{25}$.

c) Estas apreciaciones, en parte, llevaron a que las legislaciones (incluida la chilena) eliminaran la referencia legal del patrono, subsistiendo en cambio el vocablo empresario o empleador. Estos términos parecían más adecuados a la hora de representar la idea de un titular de la actividad productiva. Con todo, hay que tener presente que lo que se trata de representar en el contrato de trabajo no es sólo un titular económico de la empresa, sino que, también, y sobre todo, a un sujeto del contrato. En esa línea, la definición lingüística de empresario - como contraparte jurídica del trabajador- tampoco resulta del todo satisfactoria, ya que crea una cierta confusión entre la persona que ofrece trabajo y el titular de la unidad económica. Incluso, desde el punto de vista del lenguaje, este término da pie a diversas nociones. Así, por ejemplo, la palabra empresario puede representar a aquella persona que por concesión o por contrata ejecuta una obra o explota un servicio público ${ }^{26}$. También, es atribuible este vocablo al sujeto que abre al público y explota un espectáculo o diversión ${ }^{27}$.

Lo cierto es que, para ser considerado como contraparte del trabajador -desde la perspectiva del ordenamiento laboral- bastará con ser sujeto del

${ }^{23}$ Véase: PÉRez Botija, Eugenio, Notas sobre el concepto de empresa. Su especial consideración para el derecho del trabajo, en Revista de Derecho Mercantil, 5, 13 (1948), p. 22.

${ }^{24}$ Véase: Bayón Chacón, Gaspar - Pérez Botija, Eugenio, cit. (n. 15), I, p. 196. Véase también: De la Villa GIL, Luis Enrique, La extinción, cit. (n. 13), pp. 91-92.

${ }^{25}$ Véase: Pérez Botija, Eugenio, Notas, cit. (n. 23), p. 23.

${ }^{26}$ En igual sentido, la sentencia de la Corte de Apelaciones de Santiago de 7 de junio de 1943. En Caffarena De Jiles, Elena, Diccionario de jurisprudencia chilena ( $3^{\text {a }}$ edición, Santiago, Editorial Jurídica Ediar-ConoSur Ltda., 1986), I, p. 198.

${ }^{27}$ Véase: Diccionario de la lengua española, cit. (n. 13), I, p. 814. 
contrato y utilizar, por ende, los servicios de otra persona bajo un vínculo de dependencia jurídica inserto en un ámbito de dirección y organización. No todo empresario será necesariamente sujeto del contrato de trabajo; $\mathrm{y}$, de igual modo, no todo empresario laboral debe ser al mismo tiempo el aportante de un capital o titular dominical de bienes materiales que intervienen en la actividad. En el primer caso se encuentra el propietario de un negocio que actúa en forma aislada o con familiares no asalariados; y en el segundo, destaca la situación de un profesional independiente que utiliza los servicios de un tercero ${ }^{28}$.

d) A pesar de lo anterior, algunas legislaciones aún utilizan el término empresario como una denominación normal que prefigura al titular que actúa como acreedor del trabajo o deudor de una retribución, haciendo suyos los frutos de los servicios efectuados, y que en virtud de ello paga una remuneración determinada. Ese es el caso, por ejemplo, del artículo 1.1 del Estatuto de los Trabajadores español, el cual dispone que dicho cuerpo legal "será de aplicación a los trabajadores que voluntariamente presten sus servicios retribuidos por cuenta ajena y dentro del ámbito de organización y dirección de otra persona física o jurídica, denominada empleador o empresario". Por su parte, el inciso segundo de dicho texto legal señala que se entiende por empresarios a "todas las personas, físicas o jurídicas, o comunidades de bienes que reciban la prestación de servicios" de parte de los trabajadores. Igual denominación ocupa, en el ámbito latinoamericano, el artículo 10 del Código del Trabajo de Ecuador que define al empresario como "la persona o entidad, de cualquier clase que fuere, por cuenta u orden de la cual se ejecuta la obra o a quien se presta el servicio, se denomina empresario o empleador".

Otra referencia bastante utilizada, ahora por la doctrina, es la de acreedor de trabajo, en contrapartida con la idea de un sujeto deudor de remuneración Con dicho término se ha pretendido constituir un concepto unitario, que abarcase no sólo los supuestos jurídicos determinantes de su construcción, sino que también las manifestaciones económicas, sociales y políticas ${ }^{29}$ (representando, asimismo, el derecho que tiene el empleador a que el trabajador

${ }^{28}$ Véase: Martin Valverde, Antonio - Rodríguez-Sañudo Gutiérrez, Fermín - García Murcia, Joaquín, Derecho del trabajo (reimpresión, Madrid, Tecnos, 1992), p. 189; y Thayer Arteaga, William - Novoa Fuenzalida, Patricio, $M a-$ nual de derecho del trabajo ( $3^{a}$ edición, Santiago, Editorial Jurídica de Chile, 1998), II, p. 141.

${ }^{29}$ En esa línea, véase: De la Villa GiL, La extinción, cit. (n. 13), p. 92: "No se nos oculta, sin embargo, que, planteada así la cuestión, nos situamos en un callejón cuya única salida consistirá en el empleo de una denominación general, omnicomprensiva de ambas: acreedor de trabajo, similar a ciertas formas usadas en el extranjero (Arbeitgeber, por ejemplo)". 
cumpla la prestación laboral convenida) ${ }^{30}$. No obstante, si bien este concepto puede resultar adecuado para describir al sujeto que se obliga a remunerar el trabajo prestado por su cuenta y que hace suyos los frutos o productos de la mencionada prestación, éste no es lo suficientemente amplio para describir la problemática jurídica que prefigura a una persona como titular de la empresa y, a la vez, como deudor de una remuneración en virtud de los servicios prestados en su favor. En el ámbito laboral, como es sabido, no basta con la mera condición de acreedor, es imprescindible también la existencia de una titularidad $^{31}$. Por ello, y aun cuando la calidad de acreedor de trabajo sea admisible para justificar la condición de empleador en aquellas relaciones jurídico-laborales que se desenvuelven al margen de una empresa ${ }^{32}$, lo cierto es que lo verdaderamente distintivo es la condición de titular más que de acreedor de las prestaciones de servicios ${ }^{33}$.

Por otra parte, en el plano europeo, destacan las terminologías utilizadas en los ordenamientos italiano y alemán. El derecho germano utiliza la expresión "Arbeitgeber"34, y el itálico la de "datore di lavoro"35; nociones ambas cuya traducción literal apunta a la idea de un dador de empleo o trabajo, y que ciertamente provoca algunos equívocos conceptuales ya que con él no sería posible distinguir la persona que da trabajo - prestándolo- y la persona que da ocupación (sin perjuicio de las confusiones que se generan en la práctica en torno al verdadero titular) ${ }^{36}$. Con todo, señalemos que las expresiones "Unternehmer", del derecho alemán, "entrepreneur", del francés, e imprenditore, de la legislación italiana, han servido, también, para designar al titular de una empresa ${ }^{37}$.

${ }^{30}$ Véase: Alonso García, Manuel, El sujeto acreedor, cit. (n. 16), p. 23.

${ }^{31}$ Véase: Miñambres Puig, César, El centro de trabajo (Madrid, Servicio de Publicaciones Ministerio de Trabajo y Seguridad Social, 1985), p. 136.

32 Véase por todos: Thayer Arteaga - Novoa Fuenzalida, cit. (n. 18), II, p. 141.

${ }^{33}$ Véase: Montoya Melgar, Alfredo, El poder de dirección del empresario (Madrid, Instituto de Estudios Políticos, 1965), p. 39.

${ }^{34}$ Véase por todos el comentario efectuado por Thomas Kreuder al parágrafo 611 del BGB, en Däubler, Wolfang - Hjort Jens Peter - Hummel, Dieter - WolmeRATH, Martin, editores, Arbeitsrecht (Nomos, Baden-Baden, 2008), p. 1172.

${ }^{35}$ Véase por todos: Vallebona, Antonio, Breviario di diritto del lavoro (Torino, Giappichelli, 2013), p. 221.

${ }^{36}$ Véase: Almansa Pastor, José Manuel, cit. (n. 20), p. 42. Véase también: MiÑambres Puig, César, cit. (n. 21), p. 145: "En cualquier caso debe quedar claro que el 'dador de trabajo' [...] no puede ser confundido con el titular legal del mismo (centro de trabajo), el cual será siempre el empresario como verdadero y único titular de éste".

${ }^{37}$ Muy unido a estas referencias, el derecho portugués viene en utilizar, indistintamente, los términos e m pregador o entidade patronal, aun cuando hay que reconocer que este último vocablo se encuentra cada vez en mayor desuso. Con 


\section{La opción del derecho chileno por la voz "empleador".}

Como ya se ha dicho, el derecho chileno utiliza en forma genérica la expresión empleador en desmedro de la de empresario o patrón. Así se verifica en el artículo 3 letra a) CT., cuando se describe a aquél sujeto "que utiliza los servicios intelectuales o materiales de una o más personas en virtud de un contrato de trabajo" 38 .

a) Lexicológicamente, el empleador es aquél que emplea. Es decir, el sujeto que ocupa a una persona, encargándole un negocio, comisión o puesto; o, también, el que lleva a cabo la acción por la cual se destina a alguien al servicio público $^{39}$. Desde la óptica laboral, el empleador no corresponde necesariamente a la idea de un empresario de características económicas, sino que en él se confluyen nociones básicas de una persona natural o jurídica (así como de un ente de hecho), que utiliza actual o potencialmente los servicios de un tercero en virtud de un negocio jurídico que les une previamente, mediante una retribución y bajo dependencia jurídica. Por tanto, el empleador es una parte del contrato de trabajo frente a la que se asume la obligación de trabajar y el derecho a ser remunerado.

El término "empleador" es de usual utilización en las publicaciones españolas de la Organización Internacional del Trabajo, y ella reconoce su origen en las

todo, la mención a la figura de las entidades patronales encontró en dicho país una directa consagración legislativa en el Decreto-ley No 215-C/75, de 30 de abril, sobre asociaciones patronales, la que fue definida como la persona, individual o colectiva, de derecho privado, titular de una empresa que tiene, habitualmente, trabajadores a su servicio. Las dificultades de este concepto legal, según puso de relieve la propia doctrina portuguesa, radican en el hecho de que la entidad patronal no será necesariamente un empregador, ya que la utilización de la palabra "habitualmente" pareciera cubrir una dimensión empresarial en general [Véase: Menezes Cordeiro, António, Manual de dereito do trabalho (reimpresión, Coimbra, Livraria Almedina, 1994), pp. 475-476 y 479]. En razón de lo expuesto, el propio autor propone utilizar la expresión persona laboral para todos los sujetos que intervienen en el derecho individual del trabajo como en el colectivo. Esta expresión traduciría, además de la capacidad de los sujetos laborales para ser centro de imputación de normas de derecho del trabajo, la condición de sujeto con todas las características que le confieren relevancia laboral. Así, quedarían comprendidas dentro de este esquema, el trabajador y el empresario -sea singular o colectivo-, así como los sindicatos y las asociaciones patronales (Véase: Menezes Cordeiro, cit. [n. 37], pp. 106-107).

${ }^{38}$ Cabe hacer presente, en todo caso, que el Código de 1931 sí utilizaba la voz " e m p r e s a r i o " en algunos de sus preceptos. Así ocurría, por ejemplo, y entre otros, en los artículos 55, 106, 244, 310, 317 y 333 de dicho cuerpo legal. Por su parte, la voz "p a t r ó n" aún permanece en algunos textos legales de carácter social, como es el caso de la Ley orgánica de la Dirección del Trabajo (v. gr., artículos 25, 31 y 38 del DFL. $\mathrm{N}^{\circ} 2$, de 1967).

${ }^{39}$ Véase: Diccionario de la lengua española, cit. (n. 13), I, p. 812. 
palabras empleyeur, del idioma francés ${ }^{40}$, y employer, de la cultura anglosajona. También la utiliza buena parte de los ordenamientos laborales latinoamericanos ${ }^{41}$. No obstante, y a pesar de su correcta morfología castellana, este vocablo ha sido objeto de críticas por parte de la doctrina hispanoamericana. Por ejemplo, para Alonso García ${ }^{42}$, aparte de su dificultad fonética, esta voz resultaba inadecuada ya que conjuntamente con el hecho de referirse a la persona que, como sujeto, contrata los servicios de un trabajador, sirve para indicar al que, funcionalmente, tiene la misión de emplear a los trabajadores en una especie de labor de intermediario. En igual posición se sitúa Almansa Pastor, que la considera una expresión más sociológica que jurídica, inservible para caracterizar al sujeto de la relación individual de trabajo; y que, por lo demás, su uso recuerda la inserción del trabajador en la empresa, dándole empleo, con independencia del acuerdo de voluntades ${ }^{43}$. Otros autores, por su parte, han advertido que la calidad de empleador no es exactamente asimilable a la de empresario, cuestión

${ }^{40}$ En el derecho francés se suele utilizar también, más doctrinaria que legalmente, la expresión "chef d'entreprise", en referencia a un jefe de empresa que se alza como la máxima autoridad dentro de una entidad (véase por todos: LyON-CAEN, Gérard - PÉLissier, Jean - Supiot, Alain, Droit du travail [17 a edición, Paris, Livraria Almedina, 1994], pp. 16 y 164). Muy unida a las tesis institucionalistas, esta expresión ha servido para representar a una especie de jefe del centro de trabajo -en las pequeñas y medianas empresas- o al órgano investido del poder empresarial en las sociedades anónimas. Como señalaba, en su momento, Illanes Edwards, Jaime, Empresa y derecho del trabajo, en La empresa participación de los trabajadores (Santiago, Andrés Bello, 1973), p. 97: "La principal autoridad en la empresa es el jefe de ella, sea que tome el nombre de gerente, presidente o de director ejecutivo". En el Código del Trabajo chileno aún existen referencias al "jefe". Por ejemplo, en el contrato de trabajadores embarcados, el artículo 108 señala que las disposiciones sobre jornada semanal no serán aplicables "a cualquier otro oficial que, de acuerdo con el reglamento de trabajo a bordo, se desempeñe como jefe de un departamento o servicio de la nave". Con iguales términos, el artículo 197 CT. indica que para "hacer uso del descanso de maternidad [...] deberá presentarse al 'jefe' del establecimiento, empresa, servicio o empleador un certificado médico o de matrona”. Otras normas que utilizan la misma expresión, pueden consultarse en los artículos 148 y 503 CT.

${ }^{41}$ La voz " e m p l e a r", ciertamente vinculada a la de empleador, reconoce su origen en la palabra del idioma francés arcaico "empleier", de la cual derivó a "e m plo y e u r". Ella procede, a su vez, de la expresión latina implicare, que traduce la idea de "envolver", "complicar", "meter (a alguien en alguna actividad), dedicarle (a ella)", expresiones todas que derivan de la palabra "plegar, doblar". Este término que comentamos es ya frecuente en los textos de la Edad Media, al cual se acude para representar la figura de "emplear las armas". En relación con el origen y derivaciones posteriores de la palabra, véase por todos: Corominas, Joan, Diccionario crítico-etimológico de la lengua castellana (reimpresión, Madrid, Gredos, 1954), II, p. 247.

${ }^{42}$ Véase: Alonso García, Manuel, El sujeto acreedor, cit. (n. 16), p. 23.

${ }^{43}$ Véase: Almansa Pastor, José Manuel, cit. (n. 20), p. 42. 
que queda reflejada en aquellas personas que, sin contratar los servicios de otro, influyen en las decisiones generales sobre la marcha de la empresa, de forma tal que el empresario-organizador no puede identificarse sin más con la figura del empleador ${ }^{44}$. A lo anterior, se uniría el hecho de que en algunas ocasionas la palabra en referencia ha sido ocupada, también, para designar al trabajador que funcionalmente tiene la misión de seleccionar y contratar.

A favor del uso de esta expresión se encuentran De la Villa y García Ninet ${ }^{45}$; así como Martin Valverde, Rodríguez-Sañudo Gutiérrez y García Murcia. Estos últimos consideran el término empleador mucho más preciso a efectos laborales, ya que expresaría "claramente la idea central que lo caracteriza como sujeto de la relación laboral: la persona que ofrece un empleo al trabajador asalariado, que lo emplea efectivamente y que utiliza sus servicios" ${ }^{\text {" } 6}$. En una posición similar, Palomeque López y Álvarez de la Rosa han señalado que "sólo trasciende al derecho del trabajo la característica de ser empleador, sujeto del contrato de trabajo" ${ }^{\prime 7}$.

${ }^{44}$ Véase en esta línea: GARCÍA Fernández, Manuel, Manual de derecho del trabajo (Barcelona, Ariel, 1990), p. 250. Véanse también: Alonso Olea, Manuel - Casas BAAMOnde, María Emilia, Derecho del trabajo (13 a edición, Madrid, Servicio de Publicaciones Facultad de derecho Universidad Complutense, 1993), pp. 157-158; y Montoya Melgar, Alfredo, Derecho del trabajo (29a edición, Madrid, Tecnos, 2008), p. 538.

${ }^{45}$ Véase: De la Villa Gil, Luis Enrique - García Ninet, José Ignacio, Contrato de trabajo a domicilio, en Borrajo DACRUZ, Efrén (director), Comentarios a las Leyes Laborales. El Estatuto de los Trabajadores (Madrid, Edersa, 1985), III, p. 441: "la terminología más clara para designar a las personas que prestan trabajo por cuenta de otros, y a éstos, que, en contrapartida, los retribuyen, (...), es la siguiente: trabajador, para designar a la persona que realiza la actividad; empleador, para designar a la persona que recibe y retribuye el trabajo o la actividad de que se trata, no interesando ahora que la recepción sea o no definitiva". Y agregan en p. 451: "se insiste en su utilización, no sólo por parecer el más expresivo y considerar infundadas las críticas que al parecer se dirigen basadas simplemente en su aparente ingrata fonética, sino también porque finalmente tal vocablo ha sido admitido por el legislador español en el artículo 1.1 del E.T. como sinónimo de empresario o contraparte del trabajador en el contrato de trabajo".

${ }^{46}$ Véase: Martin Valverde, Antonio - Rodríguez-Sañudo Gutiérrez, Fermín - García Murcia, Joaquín, cit. (n. 18), p. 189.

${ }^{47}$ Véase: Palomeque López, Manuel Carlos - Álvarez de la Rosa, Manuel, Derecho del trabajo (1 ${ }^{a}$ reimpresión, Madrid, Centro de Estudios Ramón Areces, 1993), p. 559. También, en posición favorable a este vocablo: De la Villa, Luis Enrique PALOMEQue López, Manuel Carlos, Introducción a la economía del trabajo (Madrid, Debate, 1978), I, p. 575: "El término empleador se va generalizando, con éxito, frente a los más inexactos de empresario y patrono, y a costa también de los más ambiguos de dador o acreedor de trabajo. La única crítica que se ha hecho a la expresión, en la doctrina española es estrictamente semántica (la "ingrata fonética" a que aluden Bayón y Pérez Botija), siendo de aceptación general en los países de habla inglesa (employer), francesa (employeur), portuguesa (empregador) y en toda Hispanoamérica”. 
En el plano latinoamericano, según indicábamos, la tendencia de varios países ha sido la de utilizar la expresión empleador. Con ella se pretende configurar a un sujeto que contrata los servicios del trabajador para la realización del fin técnico-productivo ${ }^{48}$. De esta manera, el empleador se erige como la persona que dirige la empresa -ya sea por sí o por otros- y que recibe la tarea que le brinda el trabajador, al cuál está obligado a remunerar.

b) En síntesis, volviendo al caso chileno, hay que tener presente que tanto el Código del Trabajo, como en general todo el ordenamiento jurídico nacional, ha privilegiado la utilización del término empleador, dejando de lado otras posibilidades que se observan en derechos comparados. Sin ir más lejos, la propia Constitución Politica utiliza esta voz en su artículo $57^{49}$. Con ello se ha pretendido unificar un posible concepto jurídico general del sujeto del contrato de trabajo. Más aún, esta expresión constituye una referencia eminentemente técnico-jurídica, que refleja la posición que el empleador ocupa en la relación jurídico-laboral, marcada por la condición de acreedor de trabajo y sujeto del contrato dotado de un poder de ordenación y dirección empresarial.

\section{LA CONFIGURACIÓN NORMATIVA DEL EMPLEADOR}

\section{Derecho comparado.}

Las referencias conceptuales a la empresa o al propio empleador no son una constante en los ordenamientos jurídicos comparados. Tampoco resulta usual encontrar una definición o una descripción específica de dichos térmi$\operatorname{nos}^{50}$. Reflexiones similares podrían efectuarse en relación con la figura del trabajador $^{51}$, aun cuando este último concepto resulta fácilmente deducible

\footnotetext{
${ }^{48}$ Véase: Garcia Fernandez, Manuel, cit. (n. 44), p. 250.
}

${ }^{49} \mathrm{El}$ inciso cuarto del artículo 60 de la Constitución señala expresamente que: "Cesará en su cargo el diputado o senador que ejercite cualquier influencia ante las autoridades administrativas o judiciales en favor o representación del e $\mathrm{m}$ p l e a d o r o de los trabajadores en negociaciones o conflictos laborales, sean del sector público o privado, o que intervengan en ellos ante cualquiera de las partes. Igual sanción se aplicará al parlamentario que actúe o intervenga en actividades estudiantiles, cualquiera que sea la rama de la enseñanza, con el objeto de atentar contra su normal desenvolvimiento".

${ }^{50}$ Véase CAmps Ruiz, Luis Miguel, El concepto laboral de empresario, en Borrajo DACRUZ, Efrén (director), Comentarios a las leyes laborales. El Estatuto de los Trabajadores (Madrid, Edersa, 1990), I, p. 37.

${ }^{51}$ Véanse por todos: Almansa Pastor, José Manuel, cit. (n. 20), p. 40; Molero Manglano, Carlos, y Charro Baena, Pilar, Para una perspectiva actualizada de la noción de trabajador, en Revista de Trabajo y Seguridad Social, 3 (1991), p. 40; y Sala Franco, Tomás - López Mora, Federico, Contrato de trabajo, en Borrajo DACruz, Efrén (director), Comentarios a las Leyes Laborales. El Estatuto de los Trabajadores (Madrid, Edersa, 1990), I, p. 3. 
de las diversas alusiones que las normativas laborales efectúan a la prestación de servicios bajo dependencia jurídica ${ }^{52}$. Ello explica, en parte, que las diversas normas de los textos legales utilizan las palabras empresa, trabajador, empresario o empleador, con un marcado carácter plurívoco, pero sin que esto se traduzca en un acabado concepto jurídico de aplicación general ${ }^{53}$.

Entre las legislaciones que contienen una referencia específica, se encuentran países como Irlanda e Italia. En el primero, la Ley de despidos improcedentes del año 1977 definió al empresario como "la persona por quien el trabajador está, o estuvo empleado, en virtud de un contrato de trabajo". En Italia, por su parte, el Código Civil concibe al empresario como alguien que "profesionalmente lleva a cabo una actividad económica, con el objeto de producir o intercambiar bienes o servicios". Y, en su artículo 2086, se le describe como la cabeza de la empresa, dependiendo jerárquicamente de él sus colaboradores. Esta definición permite distinguir claramente entre "empresario", en sentido amplio, y "empleador", ya que los artículos transcritos dejan al descubierto conceptos que no tienen una exacta connotación laboral.

Esta práctica legislativa de algunos Estados miembros de la Unión Europea contrasta vivamente con los cuerpos sociales latinoamericanos, los cuales tienden a establecer de manera directa una definición de la figura del acreedor de trabajo. Si bien es cierto que no todas ellas son coincidentes, se evidencia en dichos textos una tendencia a la conceptualización jurídica del empleador como uno de los sujetos de la relación de trabajo, concurriendo a la celebración

${ }^{52}$ La construcción jurídica del concepto de trabajador es una constante en las primeras leyes sociales. Poniendo el acento en la idea de dependencia y ajenidad, estos textos dejaron en evidencia una serie de esfuerzos tendientes a precisar la noción jurídica del obrero. Sobre la evolución histórica del concepto de trabajador, véanse, entre otros: Martin Valverde, Antonio, El concepto de trabajador por cuenta ajena, en Revista de Politica Social, 71 (1966), p. 72; Molero Manglano, Carlos, y Charro Baena, Pilar, cit. (n. 52), pp. 39-40; y Montoya Melgar, Alfredo, Ideología y lenguaje, cit. (n. 7), p. 119.

${ }^{53}$ En las legislaciones europeas, por ejemplo, no existe una definición omnicomprensiva del empleador ni tampoco de la empresa. En la mayor parte de los casos, las legislaciones han preferido el establecimiento de características generales que permiten prefigurar el "núcleo fundamental" de la idea jurídica del empleador o empresario. Una tendencia similar es posible apreciar con respecto a la definición del contrato de trabajo. Sólo en seis Estados Miembros de la Unión Europea -Alemania, Bélgica, Grecia, Países Bajos, Portugal y Reino Unido- se establece un concepto del mismo, ya sea en el Código civil o en la legislación laboral. Por el contrario, Dinamarca, Francia, Italia, Luxemburgo y España omiten una definición específica del contrato de trabajo. Sobre el particular, véanse: MANRíQuez López, Fernando, Las relaciones laborales en los paises miembros de la C.E.E., en Boletín de Estudios Económicos, 49, 151 (1994), pp. 24-27; y RodRÍGuezPiñero Royo, Miguel, La regulación del contrato de trabajo en los paises de la Comunidad Económica Europea (Madrid, Tecnos, 1989), pp. 16, 56, 84, 98 y 110. 
del contrato bajo la característica de una persona natural o jurídica. Ese es el caso, entre otros, del artículo 10 de la Ley federal de México, de 1970, que concibe al "patrón" como "la persona física o moral que utiliza los servicios de uno o varios trabajadores"; del artículo 10 del Código del Trabajo de Ecuador, de 1978, el cual denominó como empresario o empleador, a la persona o entidad, de cualquier clase que fuere, por cuenta u orden de la cual se ejecuta la obra o a quien se presta el servicio; el artículo 87 del Código de Panamá, también del año 1978, parea el cual "Empleador es la persona natural o jurídica que recibe del trabajador la prestación de servicios o la ejecución de la obra"; el artículo $26 \mathrm{de}$ la Ley de contrato de trabajo de Argentina, el cual define al "empleador" como "la persona fisica o conjunto de ellas, o jurídica, tenga o no personalidad jurídica propia, que requiera los servicios de un trabajador" "; ; el artículo 2 de la vigente Ley general del trabajo de Bolivia: "patrono es la persona natural o jurídica que proporciona trabajo, por cuenta propia o ajena, para la ejecución o explotación de una obra o empresa"; o, por último, el artículo 40 de la Ley orgánica del trabajo, de los trabajadores y de las trabajadoras de Venezuela: "se entiende por patrono o patrona, toda persona natural o jurídica que tenga bajo su dependencia a uno o más trabajadores o trabajadoras, en virtud de una relación laboral en el proceso social de trabajo".

2. La idea jurídica de empleador.

a) El Código del Trabajo chileno ha establecido una definición formal y clásica del empleador. Dicha referencia, consagrada en el artículo 3 letra a), está estructurada en términos fundamentalmente contractuales, con una referencia a la utilización de los servicios (más conectada con la ajenidad que con la subordinación), y dejando de lado expresamente la calificación de titularidad por la cual el empleador hace suyos los frutos de la prestación laboral. Es decir, de acuerdo con la actual redacción del precepto, resultan irrelevantes en la conceptualización del empleador el tipo de negocio o explotación de la cual es titular, la naturaleza de dicha titularidad, la existencia o no de un ánimo de lucro, la existencia o no de una auténtica organización productiva, o la circunstancia de que el sujeto empleador tenga una o varias empresas bajo su condición de titular.

${ }^{54}$ Véase, además, el artículo 5 inciso $2^{\circ}$ de la misma Ley, en cuya virtud el empresario es "quien dirige la empresa, por si o por medio de otras personas, y con el cual se relacionan jerárquicamente los trabajadores, cualquiera sea la participación que las leyes asignen a éstos en la gestión y dirección de la empresa". Sobre esta materia, en el derecho argentino, Véanse, por todos: FERnÁndez MADRID, Juan Carlos, Tratado práctico de derecho del trabajo (Buenos Aires, La Ley, 1990), II, p. 949; y Morando, Juan Carlos, La noción de empresa en la Ley de contrato de trabajo, en Derecho del Trabajo, 53, 2 (Buenos Aires, La Ley, 1993), p. 136. 
De esta manera, el artículo 3 letra a) CT. ha optado por describir los elementos generales que distinguen a la persona del empleador. Dichos elementos surgen de una definición abstracta que utiliza los criterios clásicos y tradicionales que históricamente han permitido configurar al sujeto acreedor de trabajo. Con todo, la definición legal se encuentra construida como una idea meramente traslaticia o refleja de la noción de trabajador ${ }^{55}$, ya que cualquier estructura definitoria parte desde la identificación de este último. El trabajador (o la persona que presta los servicios materiales o inmateriales, según la redacción del Código) se constituye así en un punto de referencia básico para la configuración del ámbito de aplicación de las normas sociales ${ }^{56}$, y termina irradiando -como figura principal del derecho laboral ${ }^{17}$ - los elementos necesarios y fundamentales para una efectiva conceptualización del empleador, en el entendido de que éste actúa como contraparte del trabajador ${ }^{58}$ En consecuencia, allí donde haya un trabajador, tendrá que haber necesariamente un empleador ${ }^{59}$.

${ }^{55}$ Cuestión muy similar puede observarse en el derecho comparado. Véase, por ejemplo: Alarcón Caracuel, Manuel Ramón, La ajenidad en el mercado: un criterio definitorio del contrato de trabajo, en Revista Española de Derecho del Trabajo, 28 (1986), p. 508; BALlester PASTOR, Inmaculada, El trabajador autónomo de la industria y de los servicios en el ordenamiento jurídico de la Seguridad Social, en Revista de Trabajo y Seguridad Social, 17 (1995), p. 37; Montalvo Correa, Jaime, Fundamentos de derecho del trabajo (Madrid, Civitas, 1975), p. 260; Rodríguez-PiÑero royo, Miguel, La presunción de existencia del contrato de trabajo (Madrid, Civitas, 1995), p. 204; y del mismo autor, Cesión de trabajadores y empresas de trabajo temporal (Madrid, Centro de Publicaciones Ministerio de Trabajo y Seguridad Social, 1992), p. 337.

${ }^{56}$ Incluso, si se analiza la evolución histórica del derecho del trabajo se tendrá que concluir que éste aparece cualificado por el sujeto destinatario de sus normas, que no es otro que la persona que ejecuta una prestación de servicios bajo determinadas circunstancias. Sobre esta evolución, véanse, entre otros: Del VAlle Villar, José Manuel, Evolución doctrinal sobre el concepto de trabajador en el derecho del trabajo español, en Revista de Trabajo, 89 (1988), pp. 74 ss.; LuJAn AlCARAz, José, La contratación privada de servicios y el contrato de trabajo (Madrid, Centro de Publicaciones Ministerio del Trabajo y Seguridad Social, 1994), pp. 30 ss.; Molero Manglano, Carlos, y Charro Baena, Pilar, cit. (n. 52), pp. 39-40; Montoya Melgar, Alfredo, Ideología y lenguaje, cit. (n. 7), pp. 30 ss. y 68 ss.; y Ruiz Castillo, María del Mar, Delimitación subjetiva del derecho del trabajo, en Relaciones Laborales, 1 (1991), pp. 135 ss.

${ }^{57}$ Véase: Montoya Melgar, Alfredo, Derecho, cit. (n. 44), p. 279. Véase también: Pla Rodríguez, Américo, Curso de derecho Laboral (Buenos Aires, Depalma, 1993), I, 1, p. 143, quien recogiendo una idea de Martins Catharino, caracteriza al empresario como "el sujeto principal desde el punto de vista económico aunque sea secundario desde el punto de vista laboral, en relación al trabajador”.

${ }^{58}$ Véase: Rodríguez-Piñero Royo, Miguel, La presunción, cit. (n. 55), p. 204. Véase también: ADомeIt, Klaus, El empresario en el derecho del trabajo, en Relaciones Laborales, 2 (1988), p. 1193.

${ }^{59}$ Véase: Alarcón Caracuel, Manuel Ramón, cit. (n. 55), p. 508; y Dueñas 
La idea de empleador que establece el artículo 3 CT constituye, de este modo, una explicación lógica de la posición que éste ocupa en la relación de trabajo, la cual consiste lisa y llanamente en el derecho que tiene de recibir o utilizar la prestación de servicios - fundado en el título del contrato de trabajo-, inmerso dentro de un ámbito de organización y dirección que él mismo ha contribuido a establecer ${ }^{60}$. Una vez efectuada dicha prestación con las características anotadas, queda acreditada, también, la existencia de un contrato laboral con dos sujetos claramente definidos: un acreedor y un deudor de trabajo ${ }^{61}$.

b) En este orden de ideas, la prestación de servicios por cuenta ajena y bajo subordinación laboral constituye, en verdad, y a pesar de las críticas a que ha sido sometida históricamente, uno de los requisitos básicos que exige el Código del Trabajo chileno para que se pueda configurar efectivamente un trabajador $y$, por ende, un sujeto empleador ${ }^{62}$; más aún si se toma en cuenta que las demás exigencias legales deben ser complementadas por otras ramas del ordenamiento jurídico. Es decir, cada una de las figuras mencionadas en el artículo $3^{\circ}$, letra a)

Herrero, Laurentino Javier, El grupo de empresas y la sentencia de la Sala Cuarta del Tribunal Supremo de 30 de junio de 1993, en Relaciones Laborales, 1-16, (1995), p. 96.

${ }^{60}$ Véanse, a nivel doctrinario y entre otros: Alonso OlEA, Manuel - CASAS BAAmonde, María Emilia, cit. (n. 44), p. 158; Camps Ruiz, Luís Miguel, cit. (n. 50), p. 38; Iruzubieta Fernández, Rafael, El abuso del derecho y el fraude de ley en el derecho del trabajo (Madrid, Colex, 1989), p. 213; Martin Valverde, Antonio, Rodríguez-SaÑudo Gutiérrez, Fermín - García Murcia, Joaquín, cit. (n. 18), p. 189; Montoya Melgar, Alfredo, Derecho, cit. (n. 44), pp. 32-33 y 289; y PaloMeque López, Manuel-Carlos - Álvarez de la Rosa, Manuel, cit. (n. 48), p. 694. Véase también: Sempere Navarro, Antonio Vicente, Sobre el concepto de derecho del trabajo, en Revista Española de Derecho del Trabajo, 26 (1986), pp. 199-200.

${ }^{61}$ Véase: González OrTega, Santiago, La presunción de existencia del contrato de trabajo, en Montoya Melgar, Alfredo-Martin Valverde, Antonio-RodrígueZ-Sañudo Gutiérrez, Fermín (coordinadores), Cuestiones Actuales de derecho del trabajo. Estudios ofrecidos por los catedráticos españoles de derecho del trabajo al profesor Manuel Alonso Olea (Madrid, Centro de Publicaciones Ministerio de Trabajo y Seguridad Social, 1990), p. 790. Véase, además, Almansa Pastor, José Manuel, cit. (n. 20), p. 41; y Dueñas Herrero, Laurentino Javier, cit. (n. 59), p. 96.

${ }^{62}$ Véase, entre otros: De la Villa Gil, Luis Enrique - Mercader Uguina, Jesús R., Modelos, agencias de modelos y empresas publicitarias (Madrid, Tecnos, 1994), pp. 10-11; Molero Manglano, Carlos, Una configuración actualizada de la noción de empleador y sus problemas básicos, en Actualidad Laboral, 2 (1996), p. 506.; MonToy A Melgar, Alfredo, El poder de dirección, cit. (n. 33), p. 66; El mismo, Sobre el trabajo dependiente como categoría delimitadora del derecho del trabajo, en Revista Española de Derecho del Trabajo, 91 (1998), p. 710; Pérez de los Cobos OrIhuel, Francisco, El trabajo subordinado como tipo contractual, en Documentación Laboral, 39 (1993), p. 31; Rodríguez-PiÑero Royo, Miguel, La presunción, cit. (n. 55), pp. 201 y 204; y RoMÁn De la Torre, María Dolores, Poder de dirección y contrato de trabajo (Valladolid, Grapheus, 1992), pp. 57 y 64-65. 
CT. no es más que una referencia conceptual que deja en evidencia el hecho de que el rasgo distintivo de cada una de ellas es la posibilidad que éstas tienen de utilizar o ser receptoras de servicios, en tanto acreedor de trabajo y deudor de remuneración. Dicho esquema permite estructurar la subordinación o dependencia de manera más objetiva, reflejada en el sometimiento del trabajador a una organización jerarquizada en la cual el empleador aparece como un titular que satisface sus propios intereses y mantiene la decisión última sobre el trabajo ${ }^{63}$.

Lo anterior es de toda lógica si se considera que el criterio de la subordinación o dependencia -en cuanto elemento capaz de configurar la condición de trabajador- ha sido una constante en la evolución del derecho laboral, a pesar de que no es el único factor que define la relación de trabajo. Sin ir más lejos, ello permitió diferenciar las figuras civiles de aquellas propias de la disciplina social. Este razonamiento, plenamente aplicable en aquellas relaciones de indubitada naturaleza laboral, permite distinguir la inserción del trabajador dentro del ámbito organizativo del empleador, excluyendo de este modo los vínculos contractuales revestidos de una dependencia genérica y amplia, pero no laboral.

c) El problema, en todo caso, surge cuando se está en presencia de las denominadas figuras "anómalas", las cuales se encuentran a mitad de camino entre la contratación laboral y una de carácter civil o comercial. Para hacer frente a esta objeción hay que partir de la base de que la noción abstracta de la dependencia ya no es suficiente para resolver todas aquellas zonas grises existentes en la vida contractual ${ }^{64}$. Esa opción supondría simplificar inadecuadamente un concepto que, de por sí, reviste una complejidad y cuestionamiento que va más allá de la mera caracterización de sus indicios externos. Por ello, en la actualidad, más que hablar del donde, como y cuando de la prestación de trabajo, es preciso configurar la subordinación o dependencia como un singular modo de ser que se refleja en la inserción del trabajador dentro de una organización ajena, y en cuya virtud el titular de la misma se encuentra facultado "para dirigir la

${ }^{63}$ Como señala Montoya Melgar, Alfredo, Derecho y trabajo (Madrid, Civitas, 1997), p. 29: “La opinión dominante, sin embargo, no ha dejado en ningún momento de reconocer la fundamental función explicativa de la noción de dependencia en el contexto del contrato de trabajo y, traslativamente, del derecho del trabajo. Ahora bien: si la dependencia debe seguir siendo reputada nota esencial del trabajo regulado por el derecho del trabajo, es a condición de delimitar rectamente su sentido jurídico. Y este sentido no parece que pueda ser otro que el siguiente: la dependencia es el sometimiento del trabajador a los poderes del empresario - poder de dirección, poder reglamentario y poder disciplinario-".

${ }^{64}$ Véase: Montoya Melgar, Alfredo, Sobre el trabajo dependiente, cit. (n. 62), pp. 714-715. 
prestación de servicios, dictar órdenes, controlar su cumplimiento y, llegado el caso, para sancionar los incumplimientos del trabajador" ${ }^{65}$.

Esta conclusión sigue siendo válida, incluso, en aquellos supuestos en que las manifestaciones tradicionales de la subordinación se encuentran atenuadas - producto, entre otros factores, de la introducción de nuevas tecnologías-, toda vez que la dependencia laboral termina distinguiéndose por una disposición general del trabajador para prestar servicios dentro del ámbito organizativo del empleador ${ }^{66}$. Este mismo hecho liga la dependencia con la ajenidad, ya que en definitiva la inserción dentro del círculo rector de otra persona deja al descubierto que el resultado de los servicios efectuados por el trabajador va a ser utilizado por el empleador y se integrará necesariamente dentro del patrimonio de éste ${ }^{67}$.

En esta perspectiva, y entendiendo al trabajador como referencia nuclear en la explicación central de la figura empleadora ${ }^{68}$, toda noción sobre el sujeto que ocupe la posición de acreedor de trabajo tendrá que estructurarse de forma refleja a las características propias de la prestación de servicios sujeta a un vínculo de subordinación y dependencia laboral ${ }^{69}$ (en contraposición, por cierto, a la idea de trabajador por cuenta propia o autónomo $)^{70}$. Por ello, si dicha prestación por parte del trabajador es el elemento desencadenante de la conceptualización del empleador, habrá que tener presente que ella deberá concurrir necesariamente unida a los requisitos de voluntariedad, ajenidad y

${ }^{65}$ Véase: Lujan Alcaraz, José, cit. (n. 56), pp. 412-413.

${ }^{66}$ Ibíd., p. 417. Véase, asimismo, Goldin, Adrián, El concepto de dependencia laboral y las transformaciones productivas, en Relaciones Laborales, 1 (1996), p. 343.

${ }^{67}$ Como señala Alonso Olea, Manuel, Introducción al derecho del trabajo ( $5^{\mathrm{a}}$ edición, Madrid, Civitas, 1994), p. 61: "la dependencia es aquí inconcebible sin la ajenidad".

${ }^{68}$ Véanse: Ballester Pastor, Inmaculada, cit. (n. 55), p. 37; Camps Ruiz, cit., p. 38; y De la Villa GiL, Luis Enrique, Apuntes sobre el concepto de trabajador en el derecho español, en Cuadernos de la Cátedra de Derecho del Trabajo, 4 (1972) 2, p. 2.

${ }^{69}$ Véase, en el ámbito doctrinario y entre otros: Alonso García, Manuel, El sujeto acreedor, cit. (n. 16), p. 29; CABRERA BAZÁN, José, Ámbito de aplicación personal del derecho del trabajo, en Revista de Politica Social, 71 (1966), pp. 42 ss.; Molero Manglano, Carlos, cit. (n. 62), p. 505; Montalvo Correa, Jaime, cit. (n. 55), pp. 212 ss.; PeDrajas Moreno, Abdón - Valdés dal Re, Fernando, Contrato de trabajo y contrato de transporte: ¿Un giro en la Jurisprudencia? en Documentación Laboral, 19 (1986), pp. 101-102; Pérez de los Cobos Orihuel, Francisco, cit. (n. 62), pp. 34-35; y RodríGUez Ramos, María José, La cesión ilegal de trabajadores tras la reforma de 1994 (Madrid, Tecnos, 1995), pp. 72 y 85.

${ }^{70}$ Véase: BALlester Pastor, Inmaculada, cit. (n. 55), pp. 26 y 29-30; y MarTin VAlverde, Antonio, El ordenamiento laboral en la jurisprudencia del Tribunal Constitucional, en Revista de Politica Social, 137 (1983), p. 111. 
pago de una remuneración que exige el Código del Trabajo ${ }^{71}$. Y a dicha conclusión tendrá que llegarse, irremediablemente, mediante un sistema de indicios que permita separar el trabajo autónomo del subordinado, y cuya expresión concreta es cambiante en el tiempo ${ }^{72}$.

d) Por tanto, para construir una noción refleja o traslaticia del "empleador" no basta cualquier prestación de servicios, sino sólo aquella que se ejecute en las condiciones y circunstancias que permiten catalogar laboralmente a un individuo como trabajador dependiente. Dicho de otra manera, para poder conceptualizar a un sujeto como trabajador -y deducir de allí la existencia de un empleador- es preciso que los servicios prestados por el primero se ejecuten bajo subordinación o dependencia, de forma voluntaria, retribuidos, por cuenta ajena, y dentro del ámbito de organización y dirección del titular de la actividad, debiendo acreditarse debidamente todos estos requisitos ${ }^{73}$ De esta

${ }^{71}$ Véanse, entre otros: Alonso García, Manuel, Curso de derecho del trabajo (10a edición, Barcelona, Ariel, 1987), p. 311; Alonso Olea, Manuel - Casas BaAMONDE, María Emilia, cit. (n. 44), pp. 50 ss.; De la Villa Gil, Luis Enrique - MerCader Uguina, Jesús, cit. (n. 62), p. 10; Molero Manglano, Carlos - Charro Baena, Pilar, cit. (n. 51), p. 41; Montalvo Correa, Jaime, cit. (n. 55), pp. 192 ss.; Montoya Melgar, Alfredo, Derecho, cit. (n. 45), pp. 37-38 y 269; Ruiz CastiLlo, María del Mar, cit. (n. 56), pp. 146-147; SAla Franco, Tomás - López Mora, Federico, cit. (n. 51), pp. 6-7; Sempere Navarro, Antonio Vicente, cit. (n. 60), p. 184; Pedrajas Moreno, Abdón - Valdés dal Re, Fernando, cit. (n. 69), pp. 100 ss.; Rodríguez-PiÑero Royo, Miguel, La presunción, cit. (n. 55), pp. 150-151; y Rodríguez Ramos, María José, cit. (n. 69), p. 79. Véase también, en relación con la dicotomía entre alteridad y ajenidad: Alarcón Caracuel, Manuel Ramón, cit. (n. 55), pp. 409 ss.

72 Véase, a nivel doctrinal: Pérez de los Cobos Orihuel, Francisco, cit. (n. 62), pp. 35-36 y 45. Y agrega en p. 40: "La sabia utilización jurisprudencial del sistema de indicios [...] es el verdadero instrumento calificatorio". Véase también: BALLESTER PAstor, Inmaculada, cit. (n. 56), p. 36: "Por ello es necesario estudiar cada situación concreta y no sacar a priori relaciones de trabajo fuera del ámbito de la laboralidad. Para ello será necesario atender a determinados indicios que han ido matizándose por la jurisprudencia”; y Goldin, Adrián, cit. (n. 66), p. 347: “[...] la dependencia laboral es un concepto esencialmente flexible y adaptable, que así como ha venido incorporando' (y abarcando) manifestaciones atípicas de prestación del trabajo que el sistema productivo fue requiriendo durante las últimas décadas, está en condiciones de seguir haciéndolo en los tiempos por venir".

${ }^{73}$ Véase: Rodríguez-Piñero Royo, Miguel, La presunción, cit. (n. 55), p. 140: “[...] lo que se está afirmando es que el contrato de trabajo no se entenderá existente hasta que no se hayan probado todos sus elementos". Véase también, RoDRÍGUEZ Ramos, María José, cit. (n. 70), pp. 79 y 80: “la determinación de quien es el empresario se haría sobre la base de dos criterios: la prestación de servicios del trabajador y la retribución; a lo que podríamos añadir otros criterios: hacer suyos los frutos de dicha prestación, dar órdenes a los trabajadores y controlar la ejecución y buen fin de 
forma, la calificación jurídica del contrato de trabajo, así como de sus sujetos, debe tener en consideración el "modo" en que se prestan los servicios, más que la mera concurrencia de una actividad determinada ${ }^{74}$.

Este "modo" ciertamente tendrá que detectarse caso a caso, mediante manifestaciones concretas ${ }^{75}$; pero aun cuando exista una mutación de los indicios tradicionales en el sentido de que ellos ya no son suficientes por sí solos para configurar la dependencia, no hay que olvidar que ésta sigue siendo el elemento caracterizador del contrato. Todo ello deja en evidencia un vínculo que le impide al trabajador decidir sobre el resultado de su propia actividad ${ }^{76}$

En razón de esta estructura normativa, el empleador debe ser conceptualizado como un "titular", que recibe la "prestación de servicios" por parte de una persona natural, ya sea para que se ejecuten en su propio "ámbito de organización y dirección" o, bien, para ponerlo a disposición de otra entidad (en el caso, por ejemplo, de los procesos de descentralización productiva). Dichos servicios, además, deberán ser prestados de forma retributiva y por cuenta ajena.

Cada uno de estos elementos, según se ha señalado ${ }^{77}$, deben concurrir conjuntamente, sin perjuicio de que en algunos casos especiales se admitan elementos específicos y puntuales a fin de poner en juego la presunción de existencia de un contrato de trabajo. La única excepción a este criterio general se encuentra en aquellos supuestos en que la calificación del contrato de servicios sea dudosa, optándose en estos casos por una calificación laboral del trabajo desempeñado, en razón de la influencia de una especie de principio in dubio pro contrato de trabajo ${ }^{78}$.

e) De esta forma, y a mayor reiteración, hay que tener presente que la explicación del empleador va íntimamente unida, y en cierta medida es tributaria, de la configuración del trabajador subordinado y del contrato de trabajo. Si existe aquél, entonces es posible hablar de un empleador; por el contrario, si el trabaja-

la actividad laboral, cumplir las obligaciones de Seguridad Social, tener el carácter de legitimado activo o pasivo en los procedimientos laborales en los que fuera parte o ser titular de la empresa".

${ }^{74}$ Véase: Pérez de los Cobos Orihuel, Francisco, cit. (n. 62), p. 34.

${ }^{75}$ Véase: Montoya Melgar, Alfredo, Sobre el trabajo dependiente, cit. (n. 62), p. 721.

${ }^{76}$ Véase: Román De La Torre, María Dolores, cit. (n. 62). pp. 63-66.

${ }_{77}$ Véase: por todos, De la Villa Gil, Luis Enrique - Mercader Uguina, Jesús, cit. (n. 62), p. 12; y Rodríguez-Piñero Royo, Miguel, La presunción, cit. (n. 55), pp. 149 y 206. Incluso, este último autor agrega en p. 177: “[...] la falta de alguno de estos elementos determina en ocasiones que la presunción 'no juegue', y en otros que la misma 'se destruya' o 'se rompa'.

${ }^{78}$ Véase: Rodríguez-Piñero Royo, Miguel, La presunción, cit. (n. 55), p. 215. Véase también: Luján AlCARAZ, José, cit. (n. 56), p. 249. 
dor no concurre entonces el empresario tendrá la condición de sujeto mercantil o fiscal, pero nunca laboral. Por esto, no resulta excesivo señalar, con las reservas del caso, que al Código del Trabajo le habría bastado con hacer referencia a un sujeto que tuviese a su cargo el ámbito de organización y dirección, haciendo suyos los frutos de los servicios subordinados prestados por el trabajador ${ }^{79}$; toda vez que lo relevante no es tanto que el empleador sea persona natural o jurídica, sino que exista una prestación de servicios dependiente y por cuenta ajena dentro de un determinado ámbito organizativo. En virtud de ella, el empleador recepciona la utilidad económica de la prestación de servicios, haciendo suyos los frutos de las labores efectuadas por el trabajador ${ }^{80}$, debiéndose retribuir a éste la actividad que ha desempeñado en beneficio del empleador. Si este último no hiciera suyos los resultados de la actividad del trabajador, entonces podría prefigurarse un trabajo por cuenta propia, cuestión que tendría que excluirse del ámbito de aplicación del Código del Trabajo. Es decir, el dependiente se inserta en un sistema organizativo ajeno, en que el resultado de sus servicios termina perteneciéndole al titular de la organización productiva ${ }^{81}$.

Esta misma argumentación, entendida de forma amplia, debe uniformar la hipótesis de que todo sujeto de una relación jurídica puede ser catalogado como empleador (o trabajador) si concurren los requisitos exigidos para la configuración del contrato de trabajo ${ }^{82}$. Lo que ocurre es que lo que verdaderamente le interesa a la ley no es tanto la naturaleza jurídica de la persona contratante sino la capacidad que ésta tiene para ser beneficiario de los servicios subordinados

${ }^{79}$ En lo que se refiere a la aprehensión de los frutos del trabajo como uno de los elementos de configuración del empleador, véase: Alonso Olea, Manuel - Casas BaAmonde, María Emilia, cit. (n. 44), p. 65; Luján Alcaraz, José, cit. (n. 56), p. 349 ss.; Montoya Melgar, Alfredo, El poder de dirección, cit. (n. 33), pp. 58 ss.; y Palomeque López, Manuel-Carlos, y Álvarez de la Rosa, Manuel, cit. (n. 47), p. 649.

${ }^{80}$ Véase: Molero Manglano, Carlos, cit. (n. 62), p. 508; y Rodríguez-PiñeRo Royo, Miguel, La presunción, cit. (n. 55), pp. 207-208. Con todo, hay que tener presente que esta recepción de la "utilidad económica" del trabajo no supone necesariamente una prestación material o física, ya que lo importante es que el empleador se beneficie directa o indirectamente de la actividad desarrollada por el trabajador.

${ }^{81}$ Véase, Román de la Torre, María Dolores, cit. (n. 62), pp. 53 y 105.

${ }^{82}$ Véase: Rodríguez-Piñero Royo, Miguel, La presunción, cit. (n. 55), pp. 201 ss. En el plano jurisprudencial, véase, por todas, la sentencia de la Corte de Apelaciones de Santiago de 16 de diciembre de 1983, en Gaceta Jurídica, 43 (1984), p. 100, considerando cuarto: "[...] al definir el legislador tanto el concepto de 'empleador' como el de 'empleado', ha señalado para ambos términos un nexo o elemento común, el expresar que la utilización de los servicios intelectuales o materiales de una o más personas por parte del primero, y las prestación de los mismos por el segundo bajo dependencia o subordinación, debe hacerse 'en virtud de un contrato de trabajo"'. 
prestados por el trabajador ${ }^{83}$, atribuyéndose inicial y directamente -salvo el caso de las empresas de suministro de personal a que se refiere el artículo 183 CT.- los frutos resultantes de su actividad, dentro de un determinado ámbito organizativo y directivo. El hecho base, en definitiva, viene dado precisamente por la prestación de un servicio retribuido por cuenta ajena y dentro del ámbito de organización y dirección de quien lo recibe ${ }^{84}$. Y esos elementos no sólo sirven para hacer presumir un vínculo de laboralidad ${ }^{85}$, sino que, además, permiten configurar a los sujetos del contrato de trabajo.

f) Las reflexiones anteriores no hacen más que ampliar la figura subjetiva del contrato laboral, dejando en claro que más allá de las nomenclaturas o denominaciones utilizadas ${ }^{86}$ existe un supuesto objetivo que condiciona la aparición del empleador ${ }^{87}$. Si éste tiene personalidad jurídica, o, incluso sin tenerla (v. gr., la herencia yacente ${ }^{88}$ ), recibe servicios voluntarios bajo dependencia o subordinación ${ }^{89}$, inmerso dentro del ámbito organizacional correspondiente, entonces estaremos en presencia de un empleador ${ }^{90}$. De este modo, se logran resolver diversos problemas de apariencia empresarial -sobre todo en el caso

${ }^{83}$ Véase, Molero Manglano, Carlos, cit. (n. 62), p. 508.

${ }^{84}$ Véase: Alonso Olea, Manuel - Casas Baamonde, María Emilia, cit. (n. 44), p. 53; Luján Alcaraz, José, cit. (n. 56), pp. 277 y 281; y Palomeque López, Manuel-Carlos - Álvarez de la Rosa, Manuel, cit. (n. 47), p. 647.

${ }^{85}$ Véase: Luján Alcaraz, José, cit. (n. 56), p. 268.

${ }^{86}$ Véase: por todos, Montoya Melgar, Alfredo, Derecho, cit. (n. 44), p. 268.

${ }^{87}$ Véanse, en el ámbito de la doctrina comparada: Molero Manglano, Carlos, cit. (n. 62), p. 506: “[...] por mucha que fuese la vocación o tendencia subjetiva de quien pretenda ser empleador, si no está recibiendo servicios prestados bajo las notas constitutivas de la relación laboral, nunca será tenido por tal”; y CRUZ Villalón, Jesús, Los cambios en la organización de la empresa y sus efectos en el derecho del trabajo: aspectos individuales, en Rodríguez-PIÑERo Royo, Miguel (coordinador), El empleador en el derecho del trabajo. XVI Jornadas Universitarias Andaluzas de Derecho del Trabajo y Relaciones Laborales (Madrid, Tecnos, 1999), p. 32: "La motivación es obvia: el legislador intencionadamente no desea incluir ningún elemento definitorio de la figura del empleador, pues éste ha de ser cualquiera que actúe como contraparte".

${ }^{88}$ Sobre la actuación empleadora de los entes de hecho, véase por todos: IRURETA Uriarte, Pedro, La situación procesal, cit. (n. 2), pp. 79 ss.

${ }^{89}$ Véase, De la Villa Gil, Luis Enrique, Apuntes sobre el concepto, cit. (n. 71), pp. 8-9; y Sala Franco, Tomás - López Mora, Federico, cit. (n. 51), p. 6.

${ }^{90}$ Este argumento se puede apreciar con mayor nitidez en la redacción que utiliza el inciso $2^{\circ}$ del artículo 5 de la Ley de contrato de trabajo argentina. Allí no se hace referencia a una persona natural o jurídica, sino que a cualquier sujeto con personalidad de derecho y cuya representación se encuentra configurada en la genérica palabra qu i en. Lo anterior se ve confirmado, además, con la definición que el artículo 21 del referido cuerpo legal entrega sobre el contrato de trabajo. Según este último precepto, habrá contrato laboral, "cualquiera sea su forma o denominación, siempre que una persona fisica se obligue a realizar actos, ejecutar obras o prestar servicios en favor de la otra y bajo 
de cesión y subcontratación de trabajadores- e identificar a las personas que permanecen ocultas tras el sujeto que formalmente contrata los servicios ${ }^{91}$.

Por el contrario, si no existe un sujeto o entidad con dichas características, que se beneficie de los servicios prestados dentro de un determinado círculo de organización y dirección ${ }^{92}$, entonces nos encontraremos en presencia de una circunstancia cualificada para apoyar la declaración de inexistencia del contrato de trabajo, "capaz de enervar tanto la laboralidad presunta de una relación, como de decidir la extralaboralidad en los casos de duda" ${ }^{93}$.

\section{El artículo 3 letra a) CT.}

a) Si bien es cierto que en muchas ocasiones bastaría una alusión genérica al sujeto receptor de los servicios prestados para configurar la existencia de un empleador, no cabe duda que resulta más conveniente una explícita referencia sobre la naturaleza jurídica de las personas o entes involucrados, a fin de determinar con exactitud cual es la normativa aplicable a cada uno de ellos.

Esta última lógica es la que sigue el Código del Trabajo chileno que, a pesar de ciertas carencias conceptuales en su redacción, al menos sí establece los elementos básicos para configurar las distintas categorías de personas o entidades habilitadas para ostentar la condición de contraparte del trabajador. La norma principal, a este respecto, se encuentra como es sabido en el artículo $3^{\circ}$, letra a) CT., cuyo texto señala expresamente que para todos los efectos legales se entiende por “a) empleador: la persona natural o jurídica que utiliza los servicios intelectuales o materiales de una o más personas en virtud de un contrato de trabajo".

b) La norma del artículo 3 CT. ha pretendido tener una aplicación amplia, de carácter erga omnes, conceptualizando la figura del empleador para "todos los efectos legales". Lo anterior tiene especial importancia ya que, en principio y en abstracto, las normas jurídicas, salvo que expresamente delimiten su ámbito de aplicación, deben entenderse regidas por una vocación de generalidad, aplicable a todos los supuestos que la norma cubre ${ }^{94}$. Consecuente con lo anterior, el Código establece un concepto aplicable a otras esferas del derecho,

dependencia de ésta, durante un periodo determinado o indeterminado de tiempo, mediante el pago de una remuneración".

${ }^{91}$ Véase, a este respecto: Rodríguez-Piñero Royo, Miguel, Cesión de trabajadores, cit. (n. 55), pp. 314-315. En igual sentido: Alonso GarCía, Manuel, El sujeto acreedor, cit. (n. 16), pp. 27 y 28; LUjÁn AlCARAZ, José, cit. (n. 56), pp. 279 y 280; y Martínez Girón, Jesús, El empresario aparente (Madrid, Civitas, 1992), p. 32. De igual modo: GonZález Ortega, Santiago, cit. (n. 61), pp. 809 ss.

${ }^{92}$ Véase: Sala Franco, Tomás - López Mora, Federico, cit. (n. 51), p. 21.

${ }^{93}$ Véase: Luján Alcaraz, José, cit. (n. 56), p. 528.

${ }^{94}$ Véase: Pedrajas Moreno, Abdón, Despido y derechos fundamentales (Madrid, Trotta, 1992), p. 25. 
cuestión que permite recalcar la fuerza expansiva que se deriva precisamente de la generalidad contenida en la letra a) del artículo $3^{95}$.

El texto recién mencionado se encuentra inspirado por una innegable concepción contractualista ${ }^{96}$, sumiendo al sujeto empleador en una determinada posición o status jurídico, cuestión que le permite recibir la prestación de servicios del trabajador dependiente en base a un contrato de trabajo previamente celebrado. En virtud de lo anterior, el acto decisivo para ostentar la condición de empleador es en definitiva la capacidad que éste tiene para ser sujeto receptor de una prestación laboral ${ }^{97}$ asumiendo, en consecuencia, la calidad de sujeto de un contrato de trabajo ${ }^{98}$.

c) Al conceptualizarse en términos contractuales, resultan irrelevantes para configurar al empleador factores tan disímiles como el tipo de negocio que éste realiza, la naturaleza de la titularidad, la existencia o no de ánimo de lucro, la concurrencia o no de personalidad, el hecho de tener una o varias empresas, o el tener o no capacidad comercial. Por el contrario, lo que resulta esencial es su condición de parte de un contrato específicamente definido en el artículo 7 CT.

Por ello, y más allá del título jurídico que habilita la actuación del empleador, la relación contractual que éste celebra con el trabajador lo coloca en un status o situación legal específica que lo hace ser centro de imputaciones normativo-

${ }^{95}$ Véase: aunque con ciertas diferencias, TAtai Puchadas, Carmen, El concepto de empresario en el ordenamiento español: algunas diferencias entre la normativa laboral y de Seguridad Social, en Ius et Praxis, 5 (1999) 2, p. 48.

${ }^{96}$ Una reafirmación de la concepción contractualista, ahora a nivel jurisprudencial, puede consultarse en la sentencia de la Corte de Apelaciones de Santiago de 16 de diciembre de 1983, en Gaceta Jurídica, 43 (1983), p. 100, considerando 4: "Que, de otro lado, al definir el legislador tanto el concepto de 'empleador' como el de 'empleado', ha señalado para ambos términos un nexo o elemento común, al expresar que la utilización de los servicios intelectuales o materiales de una o más personas por parte del primero, y la prestación de los mismos por el segundo bajo dependencia o subordinación, debe hacerse 'en virtud de un contrato de trabajo"'.

${ }^{97}$ Véase: Rodríguez-Piñero Royo, Miguel, La presunción, cit. (n. 55), p. 204. Véase también: Rodríguez Ramos, María José, cit. (n. 69), pp. 84-85: "El concepto jurídico de empresario en el derecho laboral se basa fundamentalmente en dos notas: la retribución a los trabajadores y la prestación de servicios al trabajador bajo su ámbito de organización y dirección de donde se deriva la atribución de los frutos al mismo. En caso de duda la balanza se inclina en favor de atribuir la condición de empresario al que se beneficia de los servicios de los trabajadores, al que los utiliza efectivamente".

${ }^{98}$ En el plano doctrinal, véanse por todos: Alonso Olea, Manuel - Casas BAAmonde, María Emilia, cit. (n. 44), p. 65; Camps Ruiz, Luis Miguel, cit. (n. 50), p. 38; Montoya Melgar, Alfredo, Derecho, cit. (n. 44), pp. 33 y 289; y Tagliavia López, Donato, Empresario, en Montoya Melgar, Alfredo (director), Enciclopedia jurídica básica (Madrid, Civitas, 1995), II, pp. 2.757-2.758. 
laborales de conformidad a lo dispuesto por la convención, la autonomía colectiva y el ordenamiento jurídico. La expresión "status", con todo, puede llevar a más de un equívoco en cuanto a su real configuración jurídica. Con ella no se pretende hablar del goce de mayores derechos o prerrogativas extralaborales; simplemente, el término sirve para reflejar una serie de especiales situaciones en las que se encuentra el empleador ${ }^{99}$, y las cuáles le permiten ser un sujeto jurídico capaz de ejercer derechos y contraer obligaciones de carácter laboral ${ }^{100}$. Esa posición jurídica se establece, según señalamos, en directa relación con la figura del trabajador, pues es éste, en definitiva, el destinatario básico y principal de la normativa social.

d) En razón de lo anterior, el empleador, así configurado, asumirá esta condición siempre que el sujeto que le preste los servicios lo haga de forma voluntaria, por cuenta ajena, bajo la dependencia de otra persona y percibiendo por dicha actuación una retribución determinada ${ }^{101}$. Y téngase en cuenta, a este respecto, que los servicios retribuidos por cuenta ajena se prestan dentro del ámbito de organización y dirección de otra persona, denominada empleador ${ }^{102}$. Es decir, la subordinación o dependencia debe ser exigida en referencia a la prestación del trabajo dentro del ámbito organizativo del empleador.

En congruencia con estos criterios, el artículo $3 \mathrm{CT}$. no establece, para elaborar la definición del empleador, condiciones especiales o diferenciales del contrato laboral; simplemente, para constituirse en contraparte del trabajador, además de los requisitos comunes de la capacidad civil, sólo se precisa la necesaria posibilidad de ofrecer y recibir servicios bajo dependencia laboral ${ }^{103}$, en cuanto se es sujeto del contrato de trabajo. A mayor abundamiento, aquí no se requiere cumplir, en principio, ningún requisito extraordinario vinculado a la capacidad económica o mercantil del titular de la actividad productiva. Lisa y llanamente el Código se coloca en la hipótesis de que para poder configurar a un sujeto como empleador, se requiere percibir y beneficiarse de los servicios

${ }^{99}$ Véase: Montoya Melgar, Alfredo, El poder de dirección, cit. (n. 33), p. 67.

${ }^{100}$ Véase por todos: González Biedma, Eduardo, El cambio de titularidad de la empresa en el derecho del trabajo (Madrid, Centro de Publicaciones Ministerio del Trabajo y Seguridad Social, 1989), p. 134.

${ }^{101}$ Véase: Sala Franco, Tomás - López Mora, Federico, cit. (n. 51), pp. 5 ss. Véase también: Rodríguez Ramos, María José, cit. (n. 70), pp. 70-71.

${ }^{102}$ Véase: Rivero Lamas, Juan, Limitación de los poderes empresariales y democracia industrial (Zaragoza, Secretariado de Publicaciones, Universidad de Zaragoza, 1986), p. 90. Véase también: Hurtado González, Luis, El encuadramiento del empresario en la Seguridad Social, en Revista Andaluza de Trabajo y Bienestar Social, 26 (1993), pp. 84 y 88; Luján Alcaraz, José, cit. (n. 56), pp. 412 ss.; y Pedrajas Moreno, Abdón - Valdés dal Re, Fernando, cit. (n. 69), p. 102.

${ }^{103}$ Véase: Sala Franco, Tomás - López Mora, Federico, cit. (n. 51), p. 6. 
que ejecuta un trabajador dentro de un ámbito de organización y dirección predeterminado.

e) Por último, no es posible terminar estas reflexiones sin hacerse cargo de ciertos errores u omisiones que se anidan en la redacción del artículo 3 CT. Por una parte, la definición legal es extremadamente simple y clásica toda vez que parte de la base que sólo puede ser empleador una persona que ostente personificación (natural o jurídica). La práctica laboral ha dejado suficientemente en claro que existen entes de hecho, sin personalidad, que perfectamente pueden asumir la condición empleadora. Ese es el caso, por ejemplo, de la herencia yacente, los grupos de empresa, la comunidad de bienes, o las sociedades irregulares, que aun cuando carecen de personalidad jurídica igualmente tienen la posibilidad de atribuirse los frutos de la actividad desplegada por el trabajador. A pesar de ello, el Código nada dice sobre este aspecto y pretende reducir la figura empleadora a una persona natural o jurídica contradiciendo la evolución que sobre esta materia ha tenido la teoría general del derecho ${ }^{104}$.

f) Pero hay más deficiencias que es necesario anotar. La definición del Código tiene incorporada la idea implícita que el empleador controla la totalidad del ciclo productivo en el cual se inserta el trabajador. Y ello no es completamente cierto si se analizan todas las hipótesis empleadoras que regula nuestra legislación; sólo basta con observar los casos de descentralización productiva para contradecir esta creencia. Desde esta perspectiva, es curioso que el artículo $3 \mathrm{CT}$. nada diga sobre la especial naturaleza empleadora de las "empresas de servicios transitorios", las cuales, sin lugar a dudas, no controlan la totalidad del ciclo productivo. Y en rigor, tampoco son ellas las que soportan el pago de la remuneración ya que en la especial figura que ha creado el artículo $183 \mathrm{CT}$., la empresa de servicios transitorios se alza como una especie de intermediario legalmente autorizado.

No obstante, el mayor déficit que es posible reprocharle al artículo 3 letra a) CT es la indicación conceptual de que el empleador "utiliza los servicios intelectuales o materiales de una o más personas". Por de pronto, en esta frase no hay ninguna referencia explícita a la necesidad de que los servicios sean

${ }^{104}$ Véase Molina Navarrete, Cristóbal, Persona juridica y disciplina de los grupos de sociedades (Zaragoza, Publicaciones del Real Colegio de España, Bolonia, 1995), pp. 149 ss. Curiosamente, en otros cuerpos normativos, la legislación chilena sí ha sobrepasado el binomio de persona natural o jurídica para configurar al empleador. Así ocurre, por ejemplo, con el inciso primero del artículo 18 de la Ley $\mathrm{N}^{\circ} 17.322$ (de 1970) el cual indica que las "sociedades civiles y comerciales, las corporaciones y fundaciones y todas las personas jurídicas de derecho privado, las comunidades y todas las entidades y organismos particulares, [...], deberán declarar ante las instituciones de seguridad social a que estén afiliados sus dependientes, los nombres de sus gerentes, administradores o presidentes, y comunicar los cambios en esas designaciones o en el domicilio legal de unos y otros [...]". 
efectuados bajo subordinación o dependencia. Ciertamente, la deficiencia recién anotada se ve atenuada por la exigencia de que la prestación se realiza "en virtud de un contrato de trabajo", cuestión que permite vincular el concepto de empleador con los elementos que se consagran en el artículo 7 CT. Con todo, tal como está redactada la definición de empleador pareciera que el legislador está exigiendo un requisito más vinculado a la ajenidad que a la subordinación. De otra forma no se entendería la fórmula de que sólo se puede ostentar dicha condición en tanto cuanto se utilizan los servicios de otra persona. Y ello en modo alguno podría ser admisible como requisito único ya que como es ampliamente sabido la pura concurrencia de ajenidad no es suficiente para configurar la existencia de una relación laboral y tampoco de un empleador.

\section{CONCLUSIONES}

Los puntos que resumen las conclusiones de este trabajo son:

$1^{\circ} \mathrm{La}$ voz "empleador" es la que mejor refleja la posición jurídica de este sujeto del contrato de trabajo, en cuanto receptor de servicios subordinados realizados por el trabajador. Lo anterior ha implicado desechar de la legislación nacional otro tipo de términos, como "empresario" o "patrono", que lingüísticamente no daban exacta cuenta de la capacidad del empleador para utilizar los servicios del trabajador en un régimen de subordinación laboral.

$2^{\circ} \mathrm{La}$ idea jurídica de empleador es traslaticia o refleja de la noción de trabajador, ya que cualquier estructura conceptual debe partir de la identificación de éste último. En este orden de ideas, la figura del trabajador es un punto de referencia básico para construir una definición de empleador.

$3^{\circ}$ La nota distintiva para conceptualizar al empleador es su condición de contraparte del trabajador y su capacidad para recibir o utilizar la prestación subordinada de servicios fundado en el título del contrato de trabajo. De allí que, las figuras mencionadas en el artículo $3 \mathrm{CT}$. no son más que referencias conceptuales que dejan en evidencia el hecho de que el rasgo distintivo de cada una de ellas es la posibilidad de utilizar o ser receptoras de servicios subordinados.

$4^{\circ} \mathrm{La}$ idea de empleador que entrega el Código del Trabajo tiene una innegable concepción contractualista. De esta manera, resultan irrelevantes para construir la definición factores tan disímiles como el tipo de negocio que se realiza, la naturaleza de la titularidad, la existencia o no de ánimo de lucro, la concurrencia o no de personalidad, o la existencia o no de capacidad comercial.

$5^{\circ}$ Con todo, la definición legal de empleador resulta algo clásica y típica. En efecto, el Código chileno parte de la base que para tener esta calidad se 
requiere ostentar personificación, cuestión que termina contradiciendo la propia evolución que sobre esta materia ha tenido la teoría general del derecho. Asimismo, la definición parte de la idea implícita que el empleador domina la totalidad del ciclo productivo, o incluso que se vincula más con el atributo de la ajenidad que con el de la subordinación. Sin embargo, la definición de empleador sólo puede construirse a partir del concepto de trabajador subordinado, en el entendido de que aquél es la contraparte del contrato de trabajo.

\section{BIBLIOGRAFÍA}

Adомeit, Klaus, El empresario en el derecho del trabajo, en Relaciones Laborales, 2 (1988).

Alarcón Caracuel, Manuel Ramón, La ajenidad en el mercado: un criterio definitorio del contrato de trabajo, en Revista Española de Derecho del Trabajo, 28 (1986).

Almansa Pastor, José Manuel, Los sujetos del derecho del Trabajo y de la Seguridad Social, en II Encuentro Iberoamericano sobre Relaciones de Trabajo (Madrid, Servicio de Publicaciones Ministerio de Trabajo y Seguridad Social, 1984).

Alonso García, Manuel, Curso de derecho del trabajo (10ª edición, Barcelona, Ariel, 1987).

Alonso García, Manuel, El sujeto acreedor de trabajo, en Revista Jurídica de Cataluña, $60(1961) 1$.

Alonso Olea, Manuel - Casas Baamonde, María Emilia, Derecho del trabajo (13 a edición, Madrid, Servicio de Publicaciones Facultad de derecho Universidad Complutense, 1993).

Alonso Olea, Manuel, Introducción al derecho del trabajo ( $5^{a}$ edición, Madrid, Civitas, 1994).

Atienza, Manuel, Introducción al derecho (México, Distribuciones Fontamara, 1998).

Ballester Pastor, Inmaculada, El trabajador autónomo de la industria y de los servicios en el ordenamiento jurídico de la Seguridad Social, en Revista de Trabajo y Seguridad Social, 17 (1995).

Bayón Chacón, Gaspar - Pérez Botija, Eugenio, Manual de derecho del trabajo (11 edición, Madrid, Marcial Pons, 1977-1978), I.

Borrajo DACrUz, Efrén, Los auxiliares del comerciante en el derecho español, en Revista de Derecho Mercantil, 23, 63 (1957).

Cabrera BazÁn, José, Ámbito de aplicación personal del derecho del trabajo, en Revista de Politica Social, 71 (1966).

Caffarena de Jiles, Elena, Diccionario de jurisprudencia chilena ( $3^{a}$ edición, Santiago, Editorial Jurídica Ediar-ConoSur Ltda., 1986), I.

CAmps Ruiz, Luis Miguel, El concepto laboral de empresario, en Borrajo DaCruz, Efrén (director), Comentarios a las leyes laborales. El Estatuto de los Trabajadores (Madrid, Edersa, 1990), I.

CARrió, Genaro, Algunas palabras sobre las palabras de la ley (Buenos Aires, AbeledoPerrot, 1971). 
CARrió, Genaro, Sobre los límites del lenguajenormativo ( $1^{\text {a }}$ reimpresión, Buenos Aires, Astrea, 2001).

Corominas, Joan, Diccionario crítico-etimológico de la lengua castellana (reimpresión, Madrid, Gredos, 1954), II.

Cruz Villalón, Jesús, Los cambios en la organización de la empresa y sus efectos en el derecho del trabajo: aspectos individuales, en Rodríguez-PiÑERo Royo, Miguel (coordinador), El empleador en el derecho del trabajo. XVI Jornadas Universitarias Andaluzas de Derecho del Trabajo y Relaciones Laborales (Madrid, Tecnos, 1999).

Däubler, Wolfang - Hjort Jens Peter - Hummel, Dieter - Wolmerath, Martin, editores, Arbeitsrecht (Nomos, Baden-Baden, 2008).

De la Villa Gil, Luis Enrique - García Ninet, José Ignacio, Contrato de trabajo a domicilio, en Borrajo DaCruz, Efrén (director), Comentarios a las leyes laborales. El Estatuto de los Trabajadores (Madrid, Edersa, 1985), III.

De la Villa Gil, Luis Enrique - Mercader Uguina, Jesús, Modelos, agencias de modelos y empresas publicitarias (Madrid, Tecnos, 1994).

De la Villa Gil, Luis Enrique, Apuntes sobre el concepto de trabajador en el derecho español, en Cuadernos de la Cátedra de Derecho del Trabajo, 4 (1972) 2.

De la Villa Gil, Luis Enrique, La extinción del contrato de trabajo (Madrid, Consejo Superior de Investigaciones Científicas, 1960).

De la Villa, Luis Enrique - Palomedue López, Manuel Carlos, Introducción a la economia del trabajo (Madrid, Debate, 1978), I.

Del Valle Villar, José Manuel, Evolución doctrinal sobre el concepto de trabajador en el derecho del trabajo español, en Revista del Trabajo, 89 (1988).

Diccionario de la lengua española (21 ${ }^{\text {a }}$ edición, Madrid, Real Academia de la Lengua, 1992), II.

Escribar Mandiola, Héctor, Tratado de derecho del trabajo (Santiago, Zig-Zag 1944), I.

Fernández Madrid, Juan Carlos, Tratado práctico de derecho del trabajo (Buenos Aires, La Ley, 1990), II.

García Fernández, Manuel, Manual de derecho del trabajo (Barcelona, Ariel, 1990).

Goldin, Adrián, El concepto de dependencia laboral y las transformaciones productivas, en Relaciones Laborales, 1 (1996).

Gómez-Iglesias Casal, Ángel, La influencia del derecho romano en las modernas relaciones de trabajo (Madrid, Civitas, 1995).

González Biedma, Eduardo, El cambio de titularidad de la empresa en el derecho del trabajo (Madrid, Centro de Publicaciones Ministerio de Trabajo y Seguridad Social, 1989).

González Ortega, Santiago, La presunción de existencia del contrato de trabajo, en Montoya Melgar, Alfredo-Martin Valverde, Antonio-RodríguezSAÑUdo GutiéRREZ, Fermín (coordinadores), Cuestiones actuales de derecho del trabajo. Estudios ofrecidos por los catedráticos españoles de derecho del trabajo al profesor Manuel Alonso Olea (Madrid, Centro de Publicaciones Ministerio de Trabajo y Seguridad Social, 1990).

Herrero, Laurentino Javier, El grupo de empresas y la sentencia de la Sala Cuarta del Tribunal Supremo de 30 de junio de 1993, en Relaciones Laborales, 1-16 (1995).

Hurtado González, Luis, El encuadramiento del empresario en la Seguridad Social, en Revista Andaluza de Trabajo y Bienestar Social, 26 (1993). 
Illanes EDWARDS, Jaime, Empresa y derecho del trabajo, en La empresa participación de los trabajadores (Santiago, Andrés Bello, 1973).

Irureta Uriarte, Pedro, Empresa y personalidad juridica, en Persona y Sociedad, 16 (2002) 3 .

IrURETA URIARTE, Pedro, La situación procesal de los entes de hecho en el proyecto de ley que sustituye el procedimiento laboral contemplado en el Libro V del Código del Trabajo, en Cuadernos Judiciales, 8 (2004): Las reformas procesales pendientes.

IRUZubieta FERnÁNDEZ, Rafael, El abuso del derecho y el fraude de ley en el derecho del trabajo (Madrid, Colex, 1989).

LABARCA GODDARD, Eduardo, El concepto de patrón o empleador en la legislación chilena (Santiago, Editorial Jurídica de Chile, 1966).

Luján AlCaraz, José, La contratación privada de servicios y el contrato de trabajo (Madrid, Centro de Publicaciones Ministerio de Trabajo y Seguridad Social, 1994).

Lyon-Caen, Gérard - Pélissier, Jean - Supiot, Alain, Droit du travail (17a edición, Paris, Livraria Almedina, 1994).

Manrí uez López, Fernando, Las relaciones laborales en lospaises miembros de la C.E.E., en Boletin de Estudios Económicos, 49, 151 (1994).

Martin Valverde, Antonio - Rodríguez-SaÑudo Gutiérrez, Fermín - García Murcia, Joaquín, Derecho del trabajo (reimpresión, Madrid, Tecnos, 1992).

Martin Valverde, Antonio, El concepto de trabajador por cuenta ajena, en Revista de Politica Social, 71 (1966).

MARTin VAlverde, Antonio, El ordenamiento laboral en la jurisprudencia del Tribunal Constitucional, en Revista de Politica Social, 137 (1983).

Martínez Girón, Jesús, El empresario aparente (Madrid, Civitas, 1992).

Menezes Cordeiro, António, Manual de dereito do trabalho (reimpresión, Coimbra, Livraria Almedina, 1994).

Miñambres Puig, César, El centro de trabajo (Madrid, Servicio de Publicaciones Ministerio de Trabajo y Seguridad Social, 1985).

Molero Manglano, Carlos, Una configuración actualizada de la noción de empleador y sus problemas básicos, en Actualidad Laboral, 2 (1996).

Molero Manglano, Carlos, y Charro Baena, Pilar, Para una perspectiva actualizada de la noción de trabajador, en Revista de Trabajo y Seguridad Social, 3 (1991).

Molina Navarrete, Cristóbal, Persona jurídica y disciplina de los grupos de sociedades (Zaragoza, Publicaciones del Real Colegio de España, Bolonia, 1995).

Montalvo Correa, Jaime, Fundamentos de derecho del trabajo (Madrid, Civitas, 1975).

Montoya Melgar, Alfredo, Sobre el derecho del trabajo y su ciencia, en Revista Española de Derecho del Trabajo, 52 (1991).

Montoya Melgar, Alfredo, Derecho del trabajo (29a edición, Madrid, Tecnos, 2008).

Montoya Melgar, Alfredo, Derecho y trabajo (Madrid, Civitas, 1997).

Montoya Melgar, Alfredo, El poder de dirección del empresario (Madrid, Instituto de Estudios Políticos, 1965).

Montoya Melgar, Alfredo, Ideología y lenguaje en las leyes laborales de España (18731978) (Madrid, Civitas, 1992).

Montoya Melgar, Alfredo, Sobre el trabajo dependiente como categoría delimitadora del derecho del trabajo, en Revista Española de Derecho del Trabajo, 91 (1998).

Morando, Juan Carlos, La noción de empresa en la Ley de contrato de trabajo, en Derecho del Trabajo, 53, 2 (Buenos Aires, La Ley, 1993). 
Olivecrona, Karl, Lenguaje jurídico y realidad (2a edición, México, Distribuciones Fontamara, 1992).

Palomeque López, Manuel Carlos - Álvarez de la Rosa, Manuel, Derecho del trabajo (1ª reimpresión, Madrid, Centro de Estudios Ramón Areces, 1993).

Pedrajas Moreno, Abdón - Valdés dal Re, Fernando, Contrato de trabajo y contrato de transporte: ¿Un giro en la Jurisprudencia? en Documentación Laboral, 19 (1986).

Pedrajas Moreno, Abdón, Despido y derechos fundamentales (Madrid, Trotta, 1992).

PÉrez Botija, Eugenio, Notas sobre el concepto de empresa. Su especial consideración para el derecho del trabajo, en Revista de Derecho Mercantil, 5, 13 (1948).

PÉrez de los Cobos Orinuel, Francisco, El trabajo subordinado como tipo contractual, en Documentación Laboral, 39 (1993).

Pla Rodríguez, Américo, Curso de derecho laboral (Buenos Aires, Depalma, 1993), I,1.

Rivero Lamas, Juan, Limitación de los poderes empresariales y democracia industrial (Zaragoza, Secretariado de Publicaciones, Universidad de Zaragoza, 1986).

Rodríguez Ramos, María José, La cesión ilegal de trabajadores tras la reforma de 1994 (Madrid, Tecnos, 1995).

Rodríguez-Piñero Royo, Miguel, Cesión de trabajadores y empresas de trabajo temporal (Madrid, Centro de Publicaciones Ministerio de Trabajo y Seguridad Social, 1992).

Rodríguez-Piñero Royo, Miguel, La presunción de existencia del contrato de trabajo (Madrid, Civitas, 1995).

Rodríguez-PiÑero Royo, Miguel, La regulación del contrato de trabajo en los paises de la Comunidad Económica Europeo (Madrid, Tecnos, 1989).

Rojas MiÑo, Irene - Aylwin ChiorRINI, Andrés, Los grupos de empresas en el derecho chileno del trabajo (Santiago, LexisNexis, 2006).

Román DE LA TORRe, María Dolores, Poder de dirección y contrato de trabajo (Valladolid, Grapheus, 1992).

Ross, Alf, Sobre el derecho y la justicia (traducción castellana de Genaro R. Carrió, Buenos Aires, Universitaria de Buenos Aires, 1963).

Ruiz Castillo, María del Mar, Delimitación subjetiva del derecho del trabajo, en Relaciones Laborales, 1 (1991).

Sala Franco, Tomás - López Mora, Federico, Contrato de trabajo, en Borrajo DACRuz, Efrén (director), Comentarios a las Leyes Laborales. El Estatuto de los trabajadores (Madrid, Edersa, 1990), I.

Sempere Navarro, Antonio Vicente, Sobre el concepto de derecho del trabajo, en Revista Española de Derecho del Trabajo, 26 (1986).

Tagliavia López, Donato, Empresario, en Montoya Melgar, Alfredo (director), Enciclopedia jurídica básica (Madrid, Civitas, 1995), II.

Tatai Puchadas, Carmen, El concepto de empresario en el ordenamiento español: algunas diferencias entre la normativa laboral y de seguridad social, en Ius et Praxis, 5 (1999) 2.

Thayer Arteaga, William - Novoa Fuenzalida, Patricio, Manual de derecho del trabajo (3a edición, Santiago, Editorial Jurídica de Chile, 1998), II.

Vallebona, Antonio, Breviario di diritto del lavoro (Torino, Giappichelli, 2013).

YAÑEZ ANDRADE, Juan Carlos, Antecedentes y evolución histórica de la legislación social de Chile entre 1906 y 1924, en Revista de Estudios Histórico-Jurídicos, 21 (1999). 